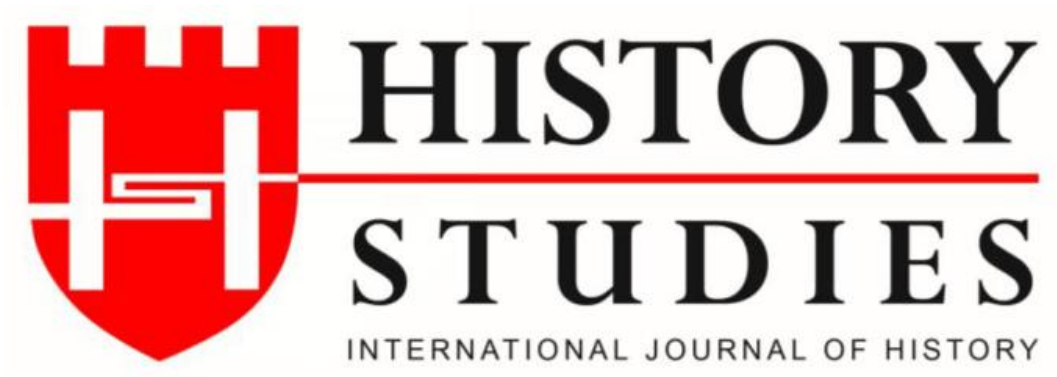

\author{
ISSN: 13094173 (Online) 1309 - 4688 (Print) \\ Volume 12 Issue 4, August 2020 \\ DOI Number: 10.9737/hist.2020.900 \\ Araştırma Makalesi \\ Makalenin Geliş Tarihi: 13.05.2020 Kabul Tarihi: 29.06.2020 \\ Atıf Künyesi: Burak Gani Erol, “Memlûkler Döneminde Şâm Mahmili, Hacılar ve Menziller”, History \\ Studies, 12/4, Ağustos 2020, s. 1809-1835.
}

\title{
Memlûkler Döneminde Şâm Mahmili, Hacılar ve Menziller
}

\author{
Bilad Al-Şham Mahmel During The Mamluks Period, Pilgrims Hajj Routes \\ Dr. Burak Gani Erol \\ ORCID No: 0000-0003-3010-4276 \\ Recep Tayyip Erdoğan Üniversitesi
}

Öz: İslâm dininin temel ibadetlerinden olan hac ibadeti, muayyen vakitlerde ve hususî yerlerde farzların yerine getirmekten ibarettir. 1250-1517 yılları arasinda Misır merkezli kurulmuş bir Türk devleti olan Memlûkler, Hicaz bölgesinin hâkimi olma sıfatıyla hac işlerinden de mesul olmuşlardır. Memlûkler devletinin kudretli sultanlarından ez-Zâhir Baybars, Mısır'dan Mekke'ye, ilk defa olmak kaydıyla, mahmil göndererek Hicaz'ın ve de Müslümanların koruyucusu olduğunu ilan etmişti. Mahmil uygulaması her ne kadar devletin temsili ile alakadar olsa, uygulanmaya başlamasından kısa bir süre sonra bir rekabet unsuru haline gelmiş ve Memlûkler Devleti'nin Mısır'dan sonra ikinci büyük merkezi olan Şâm'dan da Mekke'ye mahmil gönderilmeye başlanmıştır. Böylece, Bilâdu'şŞâm bölgesi hacılarıyla birlikte Türk, Moğol ve İranlı hacıların Hicaz'a gitmek için takip ettikleri Dımaşk merkezli Şâm hac yolu, Kâhire merkezli Mısır hac güzergâhından sonra en önemli yol olmuştur. Bu çalışmada dönemin kaynakları esas alınarak Şâm mahmilinin teşkilinden, mahmil törenlerinden, hac emîrliği müessesesinden, hacıların Hicaz'a olan yolculuklarında karşılaştıkları sıkıntılardan, hac yolu güzergâhlarından ve mezillerinden bahsedilecektir.

Anahtar Kelimeler: Hac, Memlûkler, Mahmil, Şâm, Hac Yolları

Abstract: The worship of hajj, which is one of the basic worship of the Islamic religion, consists of fulfilling its fard at certain times and in private places. Mamluks, a Turkish state founded in Egypt between 1250 and 1517, was also responsible for hajj organization as a ruler of the Hejaz region. Ez-Zâhir Baybars, one of the mighty sultans of the Mamluk state, declared that he was the protector of Hejaz and Muslims by sending mahmel from Egypt to Mecca for the first time. Although sending Mahmil was related to the representation of the state, it became a competitive element shortly after its first sending and it was started to send mahmel to Makkah from Damascus, the second largest center of the Mamluks State after Egypt. Thus, the Damascus centered Hajj pilgrimage route, which was followed by Turkish, Mongolian and Iranian pilgrims together with the pilgrims of Bilâdu'ş-Şâm region, became the most important route after the Cairo-based Egypt pilgrimage route. In this study, based on the sources of the period, the organization of Damascus mahmel will be explained. Also the ceremony of hajj organization, the hajj route to Mecca and the pilgrims faced during their journey to Hijaz will be tackled.

Keywords: Hajj, Mamluks, Mahmel, Damascus, Hajj Routes 


\section{Giriş}

Hac vazifesi İslâm'ın beş şartından birisi olup, özel şartlarını ${ }^{1}$ karşılayan her Müslümanın ömründe bir defa yapmakla mükellef olduğu bir ibadettir. 1250-1517 y1llar arasında Ortadoğu'da hüküm süren ve İslâm tarihindeki en büyük ve muktedir Türk devletleri arasında kabul edilen Memlûkler zamanında Müslümanlar kendileri üzerine farz olan bu ibadeti yapmaktaydılar. Abbasî halifesinin hâmisi ve Hicaz bölgesinin hâkimi olma sıfatlarına haiz olan Memlûkler, hem hâkimi oldukları topraklardaki Müslümanların hem de diğer İslam beldelerindeki Müslümanların hac ibadetini yerine getirmeleri hususunda oldukça etkindiler. Müslümanların hac esnasında takip edecekleri güzergâhlardan kendi hâkimiyet bölgelerindeki kısmının ve Hicaz'daki güvenliğini sağlamak, hac ibadeti boyunca Müslümanların ve kafilelerin ihtiyaçlarını ve konforunu sağlamak Memlûkler Devleti sultanlarının vazifeleri arasında addedilirdi. Aynı zamanda bu vazifeler devletin ve sultanlarının Müslümanlar ve diğer devletler nezdindeki itibar unsurları arasındaydı. Diğer taraftan Abbâsî hilafetini himaye eden devlet olma namıyla resmî hac organizasyonunu tertip etmek gibi Müslümanlar nezdindeki en şerefli vazifelerden biriside Memlûkler tarafından gerçekleştirilirdi. Memlûkler Devleti sultanı namına bu organizasyonu hac emîri / emîru'l-hacc düzenlerdi. Daha Hz. Peygamber döneminden itibaren hac ibadetini hâvi yolculuğun devlet namına idare edilip, hacılara yol boyunca ve kutsal mekânlarda rehberlik edecek, güvenliklerini sağlayacak, onların kargaşadan uzak bir şekilde vazifelerini ifa edilebilmesi maksadıyla ihdas edilen vazifeye hac emîrliği / imâretü'l-hacc adı verilmişti. ${ }^{2}$

Tüm orta çağlar boyunca İslam Dünyasında Müslümanlar dört yolu takip ederek hacca giderlerdi. Bunlar, Irak, Mısır, Şâm ve Yemen hac yollarıydı. Bu yollar arasında Dımaşk yolu, Memlûkler Devleti'nde Bilâdu'ş-Şâm ${ }^{3}$ adı verilen bölgenin hacılarının ve ayrıca Türk, Moğol ve İran hacılarının toplanma merkeziydi. Dımaşk merkezli Şâm hac yolu İslâmiyetin ilk dönemlerinden itibaren oldukça önemli olup her dönem ilgi ve ihtimama uğramıştır. Bu çalışmada Şâm hacılarının toplanma merkezi olan Dımaşk şehrini, Şâm mahmilini ve hacıların hac güzergâhlarını, yolculukları esnasında karşılaştıkları zorlukları ve mühim hadiseler, Memlûkler dönemi hakkında bilgi veren bilhassa Dımaşk menşeli kaynaklar kullanılarak bahsedilecek ve bilgi verilecektir.

\section{Mahmil'in Tanımı ve Mahmil Törenleri}

Mahmil, hevdec, şukduf ve mihfe ${ }^{4}$ gibi çeşitleri de olan ve içinde oturulmak üzere yapılmış olan ve özellikle soylu kadınların bilhassa hac yolculuğu esnasında kullandıkları, devenin üzerine yerleştirilmiş ve dekoratif olarak tezyin edilmiş tahterevan anlamına gelen bir

\footnotetext{
${ }^{1}$ Bu şartlarla ilgili olarak bkz. Salim Öğüt, "Hac: Hacla İlgili Fıkhî Hükümler”, Türkiye Diyanet Vakfi İslâm Ansiklopedisi, C. 14, TDV Yayınları, İstanbul 1996, s. 389-397.

${ }^{2}$ Mehmet Erkal, "Hac Emîrliği (Yönetimi) ve Bununla İlgili Bazı Fıkhi Meseleler", Sakarya Üniversitesi İlahiyat Fakültesi Dergisi, C. 3/4, 2001, s. 147.

${ }^{3}$ Kaynaklarda el-Bilâdu'ş-Şâmiyye yahut el-Bilâdu'ş-Şimâliyye olarak geçen ve günümüzde Suriye, Ürdün, Filistin, Lübnan ve Gazze topraklarını içine alan ve Diyarbakır'a kadar uzanan bölgeyi ifade eder.

${ }^{4} 1312$ / 711 senesinde Dımaşk’tan dört mahmil (mihfe) çıkmıştır. Bunlar hac emîri ‘Alâ'eddîn Tunboğa'nın mihfesi ve onun beraberindeki mahmilu's-sultânî, Emîr Seyfeddîn Köçkün ve 'Akabe emîri Alâ'eddîn ait mihfelerdir, İbn Fehd, en-Necm Ömer, İthâfü'l-Verâ bi-Ahbâri Ümmi'l-Kurâ, C. 3, Thk. Fehîm Muhammed Şeltût, Kâhire Mektebetü'l-Hâncî, Beyrut 1983, s. 148; Cezîrî, 'Abdulkâdir b. Muhammed, b. 'Abdulkâdir b. Muhammed, el-Ensârî ed-Dürerü'l-Ferâidi'l-Munazzamati fî Ahbâri'l-Hacc, C. 1, Thk. Muhammed Hasan Muhammed Hasan İsmâ'îl, Dâru'l-Kutubi'l-'İlmiyye, Lübnan 2002, s. 389; Berzâlî, 'Alemuddîn Ebî Muhammed el-Kasım b. Muhammed b. Yusuf, el-Muktefí alâ Kitabi'r-Ravzateyn el-Marûf bi-Târihi'l-Berzâlî, C. 2, Thk. Ömer Abdüsselam Tedmûrî, Mektebetü'l-Asriyye, Beyrut 2006, s.44.
} 
kelimedir. ${ }^{5}$ ez-Zâhir Baybars (1260-1277) dönemine kadar politik bir anlam ve önem taşımayan mahmil, deve üzerinde yolcuların, seferlerini rahatça geçirebildikleri, ahşap çerçeveli üzeri kumaşla örtülü küçük bir odayı tarif ederdi. Hac yolculuğu esnasında mahmilin bahsedilen işleviyle tarihte ilk olarak el-Haccâc b. Yûsuf (Ö. 714) tarafından kullanıldığı rivayet edilir. ${ }^{6}$ Mahmilin hac kervanlarında Kâbe örtüsüyle ${ }^{7}$ birlikte politik bir simge olarak kullanılmaya başlanması kaynaklardaki en açık bilgilere göre Sultan ez-Zâhir Baybars zamanında olmuştur. ez-Zâhir Baybars, 1266 y1lında bilinen anlamda ilk mahmili Kâhire'den Mekke'ye çıkaran sultandır. ${ }^{8}$ Onunla birlikte, mahmil ve Kâbe örtüsü, Mısır sultanının politik kudret ve gücünü, Abbâsî Halifesi üzerinden, tüm İslâm âlemine sergilediği dinî ve siyasî simgeler haline gelmişti. ${ }^{9}$

\section{2. Şâm Mahmili}

Memlûkler zamanında devletin politik gücünü temsil eden Mısır mahmili olmakla birlikte bu mahmil Memlûk ülkesinden Hicaz'a gönderilen tek mahmil değildir. Bunun haricinde, Şâm'ın Mısır'dan sonra devletin ikinci merkezi olması, Dımaşk'ın da Şâm'ın merkez şehri olması sebebiyle, Dımaşk'tan da bir mahmil çıkartılırdı. Memlûkler Devleti'nde Şâm; Dımaşk, Halep, Hamat, Tarabulus, Safed ve Kerek olmak üzere altı naibliğe ayrılmıştı. ${ }^{10}$ Bunlar arasında Dımaşk nâibliği diğer nâibliklere nazaran en büyüğü olup buranın nâibi de diğerlerine nazaran rütbece en üstteydi ve "melikü'l-ümerâ", nisbesiyle adlandırılırdı. Şâm'ın diğer naipleri Dımaşk naibine tabi idiler. ${ }^{11}$

Sultan ez-Zâhir Baybars döneminden itibaren işler hale gelen Sînâ rotasıyla birlikte başlatılan Mısır / Kâhire mahmili ve törenleriyle alakalı çok geniş malumata sahip olmamıza rağmen, kaynakların Şâm / Dımaşk mahmili ile ilgili verdiği bilgiler oldukça mahduttur. Öyle ki Şâm'dan çıkartılan hac mahmilinin ne zaman başladığına dair bilgiler dahi sınırlı ve net değildir. Memlûkler döneminde Şâm'la ilgili ilk hac haberi 31 Temmuz 1267/8 Zilkade 665 senesine kadar gitmektedir. Emîr 'İzzeddîn el-Hıllî bu tarihte Hicaz’a gitmiştir ancak onun bir

\footnotetext{
${ }^{5}$ Eyüp Sabri Paşa, Mir'âtü'l-Haremeyn, C. 2, Haz.: Ömer Fâruk Can-F. Zehra Can, Türkiye Yazma Eserler Kurumu Başkanlığı Yayınları, İstanbul 2008, s. 831-832; Serdar Mutçalı, Arapça-Türkçe Sözlük, Dağarcık Yayınları, İstanbul 1995, s. 195, 197.

${ }^{6}$ J. Jomier, "Mahmel" The Encylopaedia of Islam, C. 6, Leiden 1991, s. 44-45; Muhammed Ali al-Ahmad, "etTe'sîratü'l- 'Usmâniyye 'alâ Tarîkey el-Hacci'ş-Şâmî ve'l-Mısrî”, Akademik Platform İslami Araştırmalar Dergisi, S. 3 /1, 2019, s. 66; Burak Gani Erol, "Memlûkler Zamanında Mısır Mahmili”, Türkiyat Mecmuası, S. 29/1, 2019, s. 48-49.

${ }^{7}$ Kâbe'ye örtüyü götürme ve giydirme görevi Mısır kafilesine ve hac emîrine ait olmakla beraber 12 Mayıs 1342/5 Zilhicce 742 tarihinde Şam hac emîri 'Alâ'eddîn b. Gurlu, Halepli ve Safedli hacılarla birlikte Mekke'ye varmış ve yanında getirdiği örtüyü Kâbe'ye giydirmişti. Ondan bir gün öncede Mısırlı hacıların hac emîri Kabe'ye örtü giydirmişti. Kaynakların bildirdiğine göre bu sene Mısırlı hacıların sayısı az, Şam hacılarının sayısı ise çoktur, İbn Fehd, Ithâfü'l-Verâ, C. 3, s. 221; İbn Kâdı Şühbe, Takıyyüddîn, Tarihu İbn Kâdı Şühbe, C. 3, Thk. 'Adnân Dervîş, el-Ma'hadu'l-'İlmi el-Fransî Li'd-Dirâseti'l-'Arabiyye, Dımaşk 1977-1994, s. 236; Cezîrî, ed-Dürer, C. 1, s. 403.

${ }^{8}$ Makrîzî, Takiyyü'd-Dîn Ahmed b. 'Ali, ez-Zehebu'l-Mesbûk fî Zikri Men Hacce mine'l-Hulefâ' ve'l-Mülukk, Thk. Cemâlü'd-Dîn eş-Şeyyâl, Mektebetü't-Sekâfeti'd-Dîniyye, Bûr Sa'îd 2000, s. 17, 40; Cezîrî, ed-Dürer, C. 1, s. 200.

${ }^{9}$ Fr. Buhl, "Mahmel", İslâm Ansiklopedisi, C. 7, Milli Eğitim Basımevi, İstanbul 1977, s. 151; İbrahim Ateş, "Osmanlılar Zamanında Mekke ve Medine'ye Gönderilen Para ve Hediyeler", Vakıflar Dergisi, S. 13, 1981, s. 116.

${ }^{10}$ Kalkaşendî, Ebû'l-'Âbbâs Ahmed b. 'Ali, Subhu'l-'Aşâ fì Sinâ'ati'l-İnşâa, C. 4, Dâru'l-Kutubi'l-Misriyye, Kâhire 1922, s. 163.

${ }^{11}$ İbn Tolun, Şemseddîn, Müfâkehetü 'l-Hillân fî Havâdisi'z-Zamân, Thk. Halil el-Mansûr, Dâru'l-Kutubi'l-‘i̇lmiyye, Beyrut 1998, s. 50, 74, 190; İbn Sasrâ, Muhammed b. Muhammed, ed-Dürretü'l-Mudî'e fi'd-Devleti'z-Zâhiriyye, Thk. William M. Brinner, University of California Press, Berkeley 1963, s. 65; Sa'îd Abdu'l-Fettâh 'Âşûr, el-Asru'lMemâlîkî fî Mısr ve'ş-Şâm, Dâru'n-Nehdeti'l-‘Arabiyye, Kâhire 1976, s. 207-208.
} 
kafileyle mi tek başına mı gittiği dahi net değildir. ${ }^{12} \mathrm{O}$, haccı esnasında pahalılık ve kuraklığın hüküm sürdüğü Mekke'de bol miktarda sadaka dağıtmıştı. ${ }^{13} 24$ Ekim 1267/3 Safer 666 tarihinde Emîr Hıllî'nin hacdan Mısır'a döndüğü, Birketü'l-Hacc' da ${ }^{14}$ ez-Zâhir Baybars tarafından karşılandığı ve ardından Kudüs'ü ziyaret etmek maksadıyla tekrar yola çıktığı haberleri verilirken, Dımaşk hac kafilesinin de er-Rekbü'l-Hicâzî adıyla anılarak 30 Ekim / 9 Safer'de Dımaşk'a girdiği kaydedilmektedir. ${ }^{15} \mathrm{Bu}$ mahdut bilgilerden Dımaşk kafilesinin Emîr el-H1llî riyasetinde gitmiş olmasının mümkün olduğu ancak emîrsiz yahut başka bir emîrin idaresinde döndüğü anlaşılabilir.

1269/667 senesinde ez-Zâhir Baybars, Şâm/Tebük yolunu takip ederek Kerek üzerinden hacca gitmiştir. ${ }^{16}$ 1282/680 senesinde Dimaşk'tan Emîr Bedreddîn Güncük el-Harezmî idaresinde oldukça kalabalık bir kafileyle hac edilmiştir. Güncük idaresindeki kafileye 150 tane de memlûk de koruma olarak refakat etmiştir. Emîr Güncük kendisiyle beraber kafileyi korumak maksadıyla asker götüren ilk emîrdir. İbnü'l-Cezerî, ez-Zâhir Baybars zamanında ne bir askerin ne de bir emîrin Hicaz'a gidebilmesinin mümkün olmadığını, gidebilenlerin ise idamla cezalandırıldığını kaydeder. Ancak Sultan el-Melikü'l-Mansûr Seyfeddîn Kalavun (1279-1290) döneminden itibaren her sene tablhâne ${ }^{17}$ emîri bütün masrafları beytü'l-mâl'dan karşılanmak üzere beraberinde 120 askerle kafileye refakat ederdi. ${ }^{18}$ Cezîrî, Dımaşk hac emîrliğinden ilk defa 1283/681 senesinde bahseder. Bu yılda Misır mahmilinin ve kafilesinin hac emîri Nâsıreddîn et-Tunboğa el-Harezmî'dir. Şâm hacıları ise ilk defa bir emîr idaresinde Emîr Bedreddîn 'Abdullah es-Sevâbî ile hacca gitmişlerdir. es-Sevâbî'nin yanında ismi zikredilen Hama Kadısı Cemâleddîn İbn Vâsıl'ın ise kafile kadısı olma ihtimali vardır. Bu kafile 5 Mayıs 1283/5 Safer 682 tarihinde Dımaşk'a dönüş yapmıştır. ${ }^{19}$ İbnü'l-Cezerî'de yine bu tarihte es-Sevâbî'nin hac emîri olduğunu kaydeder. ${ }^{20}$ Şâm bölgesinin Müslümanlar tarafından fethedildiği tarihlerden itibaren, buradaki Müslümanların hac vazifelerini eda ettiklerinden mütevellit Cezîrî’nin Emîr Bedreddîn'e işaretle yazdığı “Ennehu Evvelu Emîri Velî İmretü 'l-Hacc mine'ş-Şâm” ibaresi müstakil bir hac emîrliğine işaret etmektedir. ${ }^{21}$ Yûnînî, "ez-Zeylu Mir'âti’z-Zamân" adlı eserinde 1284/682 senesi için "Ocak (Şevvâl) ayının altısında mahmil Dımaşk'tan çıktı. Emîri Sârımeddîn el-Matrûhî idi" diyerek müstakil bir Şâm mahmilinin olduğundan bahseder. Ancak anlaşılan o ki mahmil emîri bilinmeyen bir sebeple değişmiştir. Zira Yûnînî, mahmilin Safer ayının beşinde Dımaşk’a girişi yaptığını ve emîrinin

\footnotetext{
${ }^{12}$ Berzâlî, Târihu'l-Berzâlî, C. 1(1), s. 165; Cezîrî, ed-Dürer, C. 1, s. 378; Zehebî, Şemseddîn Muhammed b. Ahmed b. Osman, Târîhu'l-İslâm ve Vefeyâtü'l-Meşâhîr ve'l-A 'lâm, C. 49, Neşr. Ömer A. Tedmûrî, Dâru'l-Kütübi'l-Arabî, Beyrut 1999, s. 30.

${ }^{13}$ Cezîrî, ed-Dürer, C. 1, s. 378.

14 Burak Gani Erol, "Memlûkler Zamanında Misır Hac Güzergâhı - Kâhire'den Mekke'ye Uzanan Kutsal Yolculuk". Recep Tayyip Erdoğan Üniversitesi Illahiyat Fakültesi Dergisi, S. 16, Aralık 2019, s. 274-275.

${ }^{15}$ Berzâlî, Târihu'l-Berzâlî, C. 1(1), s. 170.

${ }^{16}$ ez-Zâhir Baybars'ın haccı ile alakalı bkz. Ramazan Şeşen, Sultan Baybars ve Devri: 1260-1277, İsar Vakfi, İstanbul 2009, s. 56-57; Burak Gani Erol, "Memlûk Sultanlarının Hacları", Tarih Okulu Dergisi, S. 12/XL, Haziran 2019, s. 317-321.

${ }^{17}$ Tablhâne: Mehter yahut bando takımına benzeyen davul, kös, zurna, zil ve kamış düdüklerden oluşan, sultanın sarayının önünde belli zamanlarda bir nevi konser veren bölüktü. Bu bölügün varoluş sebebi, savaşta düşmanın kalbine korku salmaktı. Barış zamanlarında ise kutlama münasebetiyle çalarlardı. Aynı zamanda sultanın hâkimiyet alametlerinden biriydi, İsmail Hakkı Uzunçarşıll, Osmanlı Devleti Teşkilatına Medhal, Türk Tarih Kurumu Yayınları Ankara, 1984, s.316; Altan Çetin, Memlûk Devletinde Askerî Teşkilât, Eren Yayıncılık, İstanbul 2007, s. 175-178.

${ }^{18}$ Berzâlî, Târihu'l-Berzâlî, C. 1(1), s. 538-539.

${ }^{19}$ Cezîrî, ed-Dürer, C. 1, s. 381-382.

${ }^{20}$ İbnü'l-Cezerî, Şemseddîn, Havâdisü 'z-Zamân ve Enbâuhu ve Vefeyâtü'l-Ekâbir ve'l-A yân min Ebnâihi, el-Ma'rûf bi-Tarîhi İbni'l-Cezerî, C. 1, Neşr. Ömer A. Tedmürî, Mektebetü'l-Asriyye, Beyrut 1998, s. 447; Berzâlî, Târihu'lBerzâlî, C. 2(1), s. 19.

${ }^{21}$ Cezîrî, ed-Dürer, C. 1, s. 381-382.
} 
ise et-Tavâşî Bedreddîn es-Sevâbî olduğunu nakleder. ${ }^{22}$ Cezirî eserinde 1292/691 senesi için Misır mahmilinin emîri olarak Mektûb el-'Alâ'î'yi, Şâm mahmili için Seyfeddîn el-Bâsitî’yi kaydederken, 1293/692 senesinde Mısır mahmilinin emîrî Tatah'tır. Şâm mahmilinin emîri ise et-Tayyâr adiyla maruf Bedreddîn Mesek el-Mansûrî'dir. ${ }^{23}$ 1294/693 y1lı için ise Şâm mahmilinin emîri ‘İzzeddîn Aybek et-Tavîl el-Mansûrî’dir. Şâm mahmilinin başlangıç tarihi ile alakalı olarak J. Jomier The Encyclopaedia of Islam'da 1293 (692) tarihini verir. Konuyla alakalı olarak, ez-Zâhir Baybars'ın 1266/664 tarihinde başlattı̆ğ Mısır mahmiline rakip ${ }^{24}$ olarak 1297/969 senesinde Yemen, 1319/718 tarihinde Irak mahmillerinin, 1293/692 senesinde de Şâm mahmilinin başladığını belirtir. ${ }^{25}$ Ancak bu konu ile alakalı kaynaklarda söz birliği yoktur. Yûnunî, bu yılla (1293/692) alakalı olarak hacıların et-Tayyâr el-Mansûrî olarak maruf Emîr Bedreddîn Bektaş idaresinde haccettiğini, hacıların, Mekke'ye gönderilen yardımın ve elmahmilu's-sultânî’nin Eylül (Şevvâl) ayının on dördünde yola çıktığını kaydeder. ${ }^{26}$ 'Aynî ise Misır mahmilinin emîrinin et-Tayyâr olarak maruf Emîr Bedreddîn Bektaş olduğunu, Şâm hacılarının ise Emîr el-Bâsıtî olduğunu nakleder. $\mathrm{O}$ bu sene ile ilgili olarak Takiyyüddîn $b$. Teymiyye'nin de hac edenler arasında olduğunu, Mekke'de ise çok kuvvetli bir rüzgârın çıktığını ve bu sebeple hacılardan bir kısmının öldüğünü, rüzgârın develeri ve hacıları yerlerinden attığını kaydeder. ${ }^{27}$ Berzâlî, mahmilden bahsetmeksizin Şâm kafilesinin 14 Eylül 1293/11 Şevvâl 692 tarihinde et-Tayyâr olarak maruf Emîr Bedreddîn Bîlîk el-Mansûrî idaresinde Dımaşk’tan çıktığını kaydeder. ${ }^{28}$

\section{3. Şâm Mahmilinin Hazırlıkları ve Hac İlanı}

Memlûkler zamanında hacca gitmek isteyen Müslümanların tarih olarak iki alternatifleri vardı. Kutsal mekânlarda daha fazla vakit geçirmek isteyen Müslümanlar Recep ayında küçük bir kafile ile yola çıkarlar, haccını normal zamanlar içinde yapmak isteyen Müslümanlar ise mahmil kafilesi ile birlikte Şevvâl ayında yola çıkarlardı. Hacıların Recep ayında yola çıkma âdeti Sultan ez-Zâhir Baybars ile istikrar kazanmıştır. ${ }^{29}$ Siyasî, iktisadî ve diğer koşullara göre bazı seneler, devlet resmi olarak Recep ayında hac organizasyonu düzenlemeyebilirdi. Ancak Recep ayında hacca gitmek isteyen Müslümanların kullanacakları güzergâh Mısır idi. Zira Dımaşk yolu üzerinden Recep ayında hacıların kutsal mekânlara gittiklerine dair kaynaklarda her hangi bir bilgi yoktur.

Müslümanların Şâm ve diğer beldelerden, Dımaşk yolunu kullanarak o sene hacca gidebileceğini resmi olarak ilan etmek maksadıyla Dımaşk'ta saltanat sancağı kullanılırdı. Buna göre hac kafilesinin yola çıkacağı tarihten üç ay önce, Recep ayının içindeki Cuma

\footnotetext{
${ }^{22}$ Yûnînî, Kutbüddîn, Zeylu Mir'âti'z-Zamân, C. 4, el-Mektebetü'ş-Şâmile, s. 180-181.

${ }^{23}$ Cezîrî, ed-Dürer, C. 1 , s. 383.

${ }^{24}$ Mahmillerin Kabe'ye varma hususunda da bir rekabet içinde olduğu anlaşılmaktadır. İbn Kâdı Şühbe 23 Kasım 1346 (7 Şaban 747) senesinde Şâm mahmilinin her zamanki gibi aceleyle yola çıktı̆̆ını kaydeder, Tarihu İbn Kâdı Şühbe, C.2, s.483; 1513 (919) yılı mahmillerin rekabetinin belki de en net ve çarpıcı olduğu yıllardan birisidir. Misır mahmilinin Emîri Kansuh Kert, birinci kafilenin emîri Tumanbay'dır. Şam mahmilinin emîri ise Sintbay'dır. Mısır ve Şam mahmilleri Mekke'ye erken varmak üzere yarışa girişmişler ve Şam mahmili Mısır mahmilini geride bırakarak erken varmıştır. Ancak Misırlılar bunu kendilerine yedirememişlerdir. Mekke'de mahmil devesinin ayaklarını kesip yere düşürmüşler ve sonrasında öldürmüşlerdir. Tumanbay devesiyle olay mahaline gelmiş ve kendi devesini vererek Şam mahmilinin taşınmasını sağlamıştır. Şam emîri bu durum karşısında "Ben mahmille geri dönmeyeceğim, bırakın onlar dönsünler” dediyse de Minâ'da uzlaşı sağlanmıştır, Cezîrî, ed-Dürer, C. 1, s. 491.

${ }^{25}$ J. Jomier, "Mahmel", C. 6, s. 45.

${ }^{26}$ Yûnînî, Kutbüddîn, Zeylu Mir'ati'z-Zaman, C. 20, Thk. 'Abbâs Hânî el-Cerrâh, Daru'l-Kutubil 'İlmiyye, Beyrut 2013, s. 193.

27 el-'Aynî, Bedreddîn Mahmûd b. Ahmed, 'İkdu'l-Cumân fî Tarîhi Ehli'z-Zamân, C. 3, Thk. Muhammed Muhammed Emîn, el-Hey'eti'l-Misriyyeti'l-'Amme li'l-Kitâb, Kâhire 1992, s. 190.

${ }^{28}$ Berzâlî, Târihu'l-Berzâlî, C. 1(2), s. 338.

${ }^{29}$ Burak Gani Erol, "Memlûkler Zamanında Misır Mahmili”, s. 49-50.
} 
günlerinden birinde ${ }^{30}$ sancaku's-sultânî (sancakü'l-huccâc) Dımaşk Kalesi'nden indirilir ve bundan sonraki her Cuma günü, hac zamanının geldiğinin, o sene hac yapılacağının ve hac hazırlıklarına başlanmasının alameti olarak Emevî Camisi'nin üç kapısından birisi olan Kubbetu'n-Nasr'ın altında bulunan Orta Kapı'ya dikilirdi. ${ }^{31}$ Üzerinde sultanın isminin yazılı olduğu altın işlemeli ipekten mamul sarı renkli, tepesinde altın kaplamalı gümüşten bir hilal olan bu saltanat sancağı bilahare mahmil ile yola çıkardı. ${ }^{32}$ Osmanlılar Dımaşk’’ ele geçirdikleri zaman büyük oranda yanmış olan bu Memlûk sancağını kendi sancakları ile değiştirmişlerdi. ${ }^{33}$

4 Ekim 1511/11 Recep 917 tarihinde adet olduğu üzere Dımaşk'tan haccın gerçekleştirileceği duyurulmuş ve aynı ayın on ikisinde Cuma günü de mahmil sancağı Emevî Camisi'ndeki yerine dikilmiştir. Bunun üzerine halkın üzerindeki o sene haccin yapılamayacağına dair tedirginlik yok olmuştu. Ancak, Şâban ayının ortasında, Mekke emîrlerinin fitnesi sebebiyle, Şâm yoluyla haccın iptal olduğu duyuruldu. ${ }^{34}$

30 Temmuz 1512/16 Cemaziyelevvel 918 tarihinde saltanat sancağı çıkartılıp yerine dikilmiş ve hacca gidecek olanlara hazırlıklarına başlamaları yönünde duyuru yapılmıştı. Esbay hac emîri olarak tayin edilmiş ve Onun için iyi bir ödenek de tahsis edilmişti. Ayrıca Dımaşk'ın mahallelerinde, Esbay'ın fakir olduğu ilan edilerek hacda kullanması için halktan vergi de toplanıyordu. Nihayetinde 30 Ekim / 19 Şaban'da kafile yola çıktı. ${ }^{35}$

923/1517 senesinde ise hem Araplara karşı hacıların güvenliğinin sağlanamayacağı hem de aşırı sıcak ve kuraklık gerekçesiyle Şâm kafilesinin hac yolculuğu iptal edilmişti. Bunun ilanı içinde Emevî Camisi'ne haccın o sene olacağını gösteren sancak adet olduğu üzere dikilmemişti. $^{36}$

\section{Mahmil Törenleri}

Dımaşk'taki mahmil törenleri de tıpkı Kâhire'deki törenler gibi gayet büyük ve gösterişli olup, halk ve hacılar tarafindan merakla beklenir ve izlenirdi. ${ }^{37}$ Cezerî 1326 / 726 senesinin 5 Haziran tarihinde gerçekleştirilen kutlamalarını şöyle tarif eder: "Perşembe günü (3 Recep), Mahmilu's-Sultânî, Dımaşk Kalesi'nden Sûku'l-Hayl'a doğru yola çıktı. Mahmil ile ilgili kutlamalara nâibu's-sultân ${ }^{38}$, kadılar, ayan, kurrâ', imamlar her zaman olduğu gibi katıldılar. Nâibu's-sultânın emri ile tören kıyafetleri içinde askerler hazır edildi ve bu askerler neft kullanarak bir gösteri yaptılar. Gösterilerden sonra Mahmil Emîri Seyfeddîn Çoban el-Kebîr

\footnotetext{
${ }^{30}$ Berzali 693/1294 senesi için 29 Recep tarihini, Târihu'l-Berzâlî, C. 1(1), s. 363; İbn Sasrâ 792/1390 senesi için 1 Recep tarihini, ed-Dürretü 'l-Mudî'e, s. 137; İbn Tolun ise 926/1520 senesi için 5 Şaban tarihini verir, Müfâkehetü'lHillân, s. 407, 371.

${ }^{31}$ İbn Sasrâ, ed-Dürretü'l-Mudî'e, s. 137; İbn Tolun, Müfâkehetü'l-Hillân, s. 300, 407, 371; Berzâlî, Târihu'lBerzâlî, C. 2(1), s. 363; age., C. 4 s. 230.

${ }^{32}$ Makrîzî, Takiyyü'd-Dîn Ahmed b. 'Ali, es-Sülûk li-Ma'rifeti'd-Düveli'l-Mülûk, C. 3, Thk. Muhammed 'Abdu'lKâdir 'Atâ, Dârü'l-Kutubi'l-'İlmiyye, Lübnan 1997, s. 29.

${ }^{33}$ İbn Tolun, Müfâkehetü'l-Hillân, s. 385, 371.

${ }^{34}$ İbn Tolun, Müfâkehetü'l-Hillân, s. 289.

${ }^{35}$ İbn Tolun, Müfâkehetü'l-Hillân, s. 299, 303.

${ }^{36}$ İbn Tolun, Müfâkehetü'l-Hillân, s. 372.

${ }^{37}$ Berzâlî, Târihu'l-Berzâlî, C. 2(2), s. 75, 147, 230, 375; İbnü'l-Cezerî, Tarîhu İbni'l-Cezerî, C. 2, s. 1025; İbn Sasrâ, ed-Dürretü'l-Mudî'e, s. 65.

${ }^{38}$ Sultana idarî görevlerinde yardımcı olan büyük görevliler arasında başta nâibu's-sultân gelmekteydi. Bu emîr, sultanın vekili mesabesinde olup, devlet işlerinde onun sağ kolu idi. Nâibu's-sultân, üst düzey devlet görevlilerinin atanmasında, 1ktaların dağıtılmasında ve idarî kararların alınmasında sultana yardımcı olurdu, Bahattin Keleş, "Memlûkler Döneminde İdarî Yap1", Türkler Ansiklopedisi, C. 5, Ankara, 2002, s. 592.
}

\section{History Studies}

Volume 12 
el-Mansûrî idaresinde mahmil gezdirildi. Hacılar Sûku'l-Hayl'da yolculuk için hazırlıklarını yapıp ihtiyaçlarını satın aldılar.,"39

Cezerî’nin de ifade ettiği gibi hemen tüm devlet protokolünün hazır olduğu mahmil törenlerinde, mahmil önceden belirlenmiş bir güzergâhta gezdirilerek halka gösterilirdi. Ancak mahmil gezdirilmeden önce törenin en önemli kısımlarından olan Memlûk askerlerinin oyunları halk ve protokol tarafından izlenirdi. Mahmil kutlamalarının önemli bir parçası olan kırmızılar giyinmiş, mızraklı süvariler mızrakları ile fevkalade gösteriler yapar, görenlerin ve seyredenlerin ağızları açık kalırdı. Askerler bu gösteriler için bütün bir sene ekip olarak çalışırlardı ve her birisi gösteri için özel bir öneme sahipti. Neft kullanılarak sergilenen bu oyunlarda, Memlûk askerleri bazen bireysel bazen de ekip olarak maharetlerini sergilerlerdi. ${ }^{40}$ 1390/792 senesinin Haziran (Recep) ayında mahmil Dımaşk'ta gezdirildikten hemen sonra emîrler arasında olaylar patlak vermişti. ${ }^{41}$ İbn Sasrâ yaşanan siyasî mücadelenin hacca olan etkisini şöyle yansitır: "Aynı yılın Şevvâl ayının 10'una kadar (21 Eylül) hacla ilgili herhangi bir hareketlenme olmamışt. Anadolu'dan da hiç kimse hac için gelmemişti. Üstelik hac emîri de tayin edilmemişti. Halk hac olmayacă̆ endişesine kapılmuştı. Oysaki Hz. Peygamber'in "Huccû Kable En Lâ Tahuccû" (Hacca gidemez hale gelmeden önce hacca gidiniz) şeklinde hadisi vardır. Bazı tarihçilerin bununla ilgili örnekleri de vardır. Onlar 1371/772 ve 1378/779 senelerinde hac yapılamadığını kaydetmişlerdir. Ancak korkulan olmadı mahmil ayın 19'unda (30 Eylül) hazlrlandl. Lakin sanki bir garibin cenazesiymiş gibi ne önünde ne arkasında kimse yoktu. Ne saltanat sancă̆l ne de herhangi bir kutlama söz konusu değildi. ${ }^{, 42}$ Bir sonraki sene ise (1391/793) Dımaşk'ta çıkan olaylar sebebiyle mahmilin gezdirilmesi durdurulmuş, caddeler kan gölüne dönmüştü. Öyle ki şehir halkı patlamalar sebebiyle uyuyamamışt1. ${ }^{43} \mathrm{Bu}$ sene hacca giden de çok olmamıştı. ${ }^{44}$

\section{Mahmilin Tekrar Dolaştırılması}

Üç senelik bir aranın ardından 1394/796 senesinin Mayıs (Recep) ayında mahmil tekrar Dımaşk caddelerinde dolaştırılmış ve halk da büyük bir ihtimamla süslenmiş mahmilin adet olduğu üzere gezdirilmesinden çok hoşnut kalmıştı. ${ }^{45}$ 1404/806 senesinde ise Şâm nâibinin hazırladığı mahmil Mekke'ye gidecekti. Dımaşk yolundan Mekke'ye hac 1401/803 yılından itibaren durdurulmuş ve mahmil çıkartılmamıştı. Hacıların Medine yolunu kullanacakları duyuruldu. Sarı ipek kumaşlarla süslenen mahmil için 35 bin dirhem gümüş para harcanmıştı. Mahmil Emîri Fâris, Devadâr ise Emîr Tenem idi. ${ }^{46}$ Recep ve Şevvâl aylarında olmak üzere iki sefer dolaştırılan mahmilin 1504/909 senesinde Şubat (Ramazan) ayının başında ve daha sonra Mart (Şevvâl) ayının beşinde, normal tarihten sapılarak, yaklaşık bir aylık süre içinde iki sefer dolaştırılması ise insanlarda büyük şaşkınlığa yol açmıştı. ${ }^{47}$

\footnotetext{
${ }^{39}$ İbnü'l-Cezerî, Tarîhu İbni'l-Cezerî, C. 2, s. 110; Berzâlî'de benzer bir törenden 1328/728 senesi için bahseder, Târihu'l-Berzâlî, C. 2(2), s. 323, 336.

${ }^{40} \mathrm{Bu}$ oyunlarla alakalı daha geniş malumat için bkz. Burak Gani Erol, "Memlûkler Zamanında Mısır Mahmili”, s. 50-52.

${ }^{41}$ İbn Kâdı Şühbe, Tarihu İbn Kâdı Şühbe, C. 1, s. 342-343.

42 İbn Sasrâ, ed-Dürretü'l-Mudî'e, s. 69-70.

${ }^{43}$ İbn Sasrâ, ed-Dürretü'l-Mudî'e, s. 84.

${ }^{44}$ İbn Sasrâ, ed-Dürretü'l-Mudî'e, s. 99.

${ }^{45}$ İbn Sasrâ, ed-Dürretü'l-Mudî'e, s. 158, 169.

46 İbn İyâs, Muhammed b. Ahmed, Bedâ'iu'z-Zuhûr fî Vakâi'i'd-Duhûr, C. 1(2), Thk. Muhammed Mustafâ, elHey'etü'l-Misriyyeti'l-'Ammeti'l-Kutub, Kâhire 1984, s. 686-687; İbn Hacer el-'Askalanî, Ebû'l-Fazl Şihâbüddîn Ahmed b. Alî b. Muhammed, İnba'u'l-Ğumr bi Ebnai'l-'Umr, C. 2, Thk. Hasan Habeşî, el-Meclisu'l-'A'layi li'şŞu'ûni'l-İslamiyye, Kâhire 1969, s. 267 İbn Kâdı Şühbe, Tarihu İbn Kâdı Şühbe, C. 4, s. 252.

${ }^{47}$ İbn Tolun, Müfâkehetü'l-Hillân, s. 220; İbn Tolun, Şemseddîn,I'lâmü'l-Verâ bi-men Vulliye Nâiben mine'l-Etrâk bi-Dımaşki’l-Kübrâ, C. 2, Thk. 'Abdülazîm Hâmid Hattâb, Matba'tu Cami’ati ‘Ayni Şems, Kâhire 1973, s. 173.
} 
1517/923 senesinin Eylül (Ramazan) ayında Şâm mahmili, artık Osmanlı hâkimiyeti altındaki Dımaşk'ta törenlerle şehri dolaşmıştı. Kumaşlarla süslenmiş atlar, hecin develeri, binek develeri, gösterişli zırhlara bürünmüş piyadeler sancaklarla dâru's-sa'ade'den çıkmışlar ve şehri dolaştıktan sonra geri dönmüşlerdir. Tören oldukça gösterişli geçmişti. Memlûkler döneminden tek farkı sancağın üzerinde Osmanlı Devleti Sultanı II. Selim'in isminin yazılı olmasıydı. Şâm nâibi Canberdi el-Gazâlî, Yelboğa Camisi'nin büyük penceresinin önünde oturmuş, mahmil devesi onun önüne gelmiş, burada deve ön dizlerinin üzerine çöküp kalkarak sembolik olarak yer öpme merasimi gerçekleşmişti. ${ }^{48}$

Mahmil ve devesi törenler haricinde Dımaşk Kalesi'nde hususî olarak kendisine ayrılmış beytü'l-mahmil yahut dâru's-sa'âde adlı bir kısımda muhafaza edilirdi. ${ }^{49} 23$ Aralık 1391/25 Muharrem 794 tarihinde mahmil Dımaşk'a her hangi bir kutlama olmaksızın giriş yapmıştı. Mahmilin önünde ve arkasında hiç kimse yoktu, tek başınaydı. Mahmil emîri Akboğa elBezlârî mahmil devesinin yularından tutarak tek başına kaleye çıkartmış ancak hayvanın inadını kırarak onu yerine sokamamıştır. ${ }^{50}$

\section{6. Şâm Mahmilinin ve Hac Kafilesinin Yola Çıkışı}

Genellikle Şevvâl ayının ortasında yahut özel durumlara göre Şevvâl ayı içinde her hangi bir tarihte yola çıkan kafilenin büyüklügü hacı adaylarının, devlet ricâlinin ve bürokratların iltifatına göre yıldan yıla değişiklik gösterirdi. 26 Ocak 1314/8 Şevvâl 713 tarihinde Şâm hacıları Dımaşk'tan Hac Emîri et-Tatarî olarak maruf Seyfeddîn Balaban riyasetinde yola çıkmış ve bu sene Anadolu'dan ve diğer doğu ülkelerinden uzun zamandır benzeri görülmemiş bir şekilde katılım olmuştu. Emîr Seyfeddîn Kutlu Bey el-Çaşnigir Dımaşk'ın hemen çıkışında et-Tatarî’nin yerine hac emîri tayin edilmişti. 18 Mayıs 1314/2 Safer 714 tarihinde bu kafile Dımaşk'a dönmüştü. Böylelikle kafile yaklaşık üç buçuk aydan fazla süreyle hac için Dımaşk'tan uzak kalmıştı. ${ }^{51}$

1323/723 senesinde ise kafileye çok sayıda Doğulunun katıldığı kaydedilir. Bunlar arasında Abaka b. Hülagü'nin kızı, Argun'un kızkardeşi, Gazan ve Olcaytu'nun halası da vardı. Gelen bu konuklara saygıda kusur edilmemiş ve Kasru'l-Ablak'ta misafir edilmişlerdi. Hac emîri Kutluca el-Ebû Bekrî, kafile kadısı Şemseddîn İbn Kâdi'l-Kudât Müslim el-Hanbelî, Cemâleddîn el-Mezî, Misırlllardan ise Bedreddîn b. Cemâ'a ve oğlu 'İzzeddîn, Kâtip Fahreddîn, Şemseddîn el-Hârisî, Şehâbeddîn el-Ezra'î, Alâ'eddîn el-Fârisî hac edenler arasindayd $1 .{ }^{52}$

1328/728 senesinde Fahreddîn Osman b. Şemseddîn Lü'lü el-Halebî idaresinde yola çıkan mahmil de yaklaşık 15.000'den fazla deve bulunmaktayd $1 .{ }^{53}$ 1330/731 senesinde hac emîri 'İzzeddîn Aybek, Kafile kadısı ise Şehâbeddîn b. et-Tâhirî idi. Kafileyle birlikte gidenler arasında Şehâbeddîn b. Cehîl, İbn Cümle Fahreddîn el-Mısrî ve daha başka kadılar ve bürokratlar vardı. Ayrıca kafilede dört yüz fakih, dört medrese bir hankah ve bir de dâru hadîs alimi daha bulunmaktaydi ${ }^{54}$

Mahmil ve hacıların şehre dönüşleri de, tıpkı gidişleri gibi törenlerle ve kutlamalarla olur, mahmili uğurlayan protokol dönüşte de yerini alırdı. Ancak beklenilmeyen sebepler dolayısıyla

\footnotetext{
${ }^{48}$ İbn Tolun, Müfâkehetü'l-Hillân, s. 385.

${ }^{49}$ İbn Sasrâ, ed-Dürretü' 'l-Mudî'e, s. 111; İbn Tolun, Müfâkehetü'l-Hillân, s. 385.

${ }^{50}$ İbn Sasrâ, ed-Dürretü'l-Mudî'e, s. 111-112.

${ }^{51}$ Berzâlî, Târihu'l-Berzâlî, C. 2(2), s. 117, 128.

52 İbn Kesîr, Ebû'l-Fidâ', el-Bidâye ve'n-Nihâye, C.16, Thk. Abdullah b. Abdu'l-Muhsin et-Türkî, Hecr, Cîze 1998, s.130; age, C. 18 , s. 226.

${ }^{53}$ İbnü'l-Cezerî, Tarîhu İbni'l-Cezerî, s. 268.

${ }^{54}$ İbn Kesîr, el-Bidâye, C. 18, s. 336; İbnü’l-Cezerî, Tarîhu İbni 'l-Cezerî, C. 2, s. 469.
} 
karşılama töreninin yapılamadığı zamanlarda vakiydi. 1357/758 senesinde mahmil mutat olduğu üzere gündüz erken saatlerde değil, meşaleler eşliğinde akşam karanlığında şehre giriş yapmış ve pek çok insanın da mahmilin geldiğinden haberi olmamıştı. Zira halk şiddetli yağmur ve çamur korkusu sebebiyle evlerinden çıkamamıştı. ${ }^{55} 21$ Kasım 1361/22 Muharrem 763 tarihinde ise hacılar Dımaşk'a giriş yapmışlar, hacılardan bir gün sonra da mahmil akşama doğru şehre giriş yapmıştı. Mahmilin girişi esnasında ve sonrasında adet olduğu üzere her hangi bir kutlama yapılmadı. Çünkü mahmil dönüş yolunda iken Zeyrâ' ve Dımaşk arasında havanın soğukluğu sebebiyle denildiğine göre yüzden fazla hacı donarak ölmüştü. ${ }^{56}$

Kaynaklar Dımaşk'tan her sene mahmil çıkartıldığına ve bir hac emîrî tayin edildiğine dair bilgi vermemektedir. Bunun sebebi ise Dımaşk üzerinden hacca giden az sayıdaki Şâm ve diğer bölgelerin hacılarının, Mısır üzerinden hacca gitmiş olmalarıdır. Örneğin; 1300/699 senesinde Şâm'dan kimse hacca gidememiş, mahmil çıkmamıştır. Gidebilenler Mısır üzerinden gitmişler. ${ }^{57} 1301 / 700$ senesinde de Dımaşk'tan ne resmi bir kafile ne de mahmil ${ }^{58}$ çıkmamış, gidenler Dımaşk üzerinden Gazze'ye gitmişler, buradan da 'Akabe Eyle'ye gidip Mısırlı hacılarla buluşarak yollarına devam etmişlerdir. ${ }^{59}$ 1310/709 senesinde dâhili sorun ve karışıklıklar sebebiyle tüccarlar haricinde Şâm'dan hacca gidebilen olmamıştı. Bu tüccarlar da Dımaşk üzerinden Gazze'ye buradan 'Akabe Eyle'ye gitmişler, 'Akabe'de Mısır hac kafilesine katılarak yollarına devam etmişlerdi. ${ }^{60}$ 1402/804 senesinde Timur'un (1370-1405) Dımaşk'a saldırması ve şehri yakması sebebiyle bu sene ve sonrasındaki sene hac mahmili çıkartılmamış Irak ve Yemen de dâhil olmak üzere hacca gidebilen de olmamıştır. ${ }^{61} 1406 / 808$ senesinde de Şâm'dan ne mahmil çıkmış ne de bu yolu kullanarak hacca giden olmuştur. Sadece tüccarlar Gazze-'Akabe yolunu kullanarak Mısır kafilesi ile hac yapmışlardır. ${ }^{62}$

\section{Halep Mahmili}

Dımaşk'tan çıkartılan mahmil, Memlûkler Devleti'nin ikinci büyük merkezi olan Dımaşk'tan Şâm'ı temsilen hazırlanan ve çıkartılan bir mahmildi. Ancak kaynakların verdiği bilgilere göre, Dımaşk merkezli mahmil Şâm'dan çıkartılan yegâne mahmil değildi. Hususî durumlar sebebiyle (savaş, iç karışıklık, tabi afetler vb.) Dımaşk'tan mahmil çıkartılamadığı dönemlerde Halep'ten mahmil çıkartılmıştır. Halep mahmiline kaynaklarda ilk defa 1385/787 senesinde rastlanılmakta ve bu sene Haleplilerin mahmille hac yaptıklarını ve bu durumun daha önce görülmemiş bir şey olduğu nakledilmektedir. ${ }^{63}$ İbn Kâdı Şühbe'de aynı yılda (1385/787) Haleplilerin saltanat mahmili ile hacca geldiklerini ve bunun daha önce görülmediğini kaydeder. O bu tarihte Halep'teki, daha öncekiler kadar olmasa da yine de büyük olarak addedilebilecek olan, vebanın sona erdiğini, bunun etkilerine rağmen kafilede çok sayıda Halepli hacı olduğundan bahseder. Kafile içinde çok sayıda emîr de vardı. Dımaşk'tan hareket eden kafilenin emîri ise (emîru rekbi'ş-Şâmî) Emîr Cebrâîl'di. ${ }^{64}$ Halep'ten gelen bu mahmilin,

\footnotetext{
${ }^{55}$ İbn Kâdı Şühbe, Tarihu İbn Kâdı Şühbe, C. 3, s. 115.

${ }^{56}$ İbn Kesîr, el-Bidâye, C. 18, s. 649; İbn Kâdı Şühbe, Tarihu İbn Kâdı Şühbe, C. 3, s. 200.

${ }^{57}$ Cezîrî, ed-Dürer, C. 1, s. 386, İbn Fehd, İthâfü'l-Verâ, C. 3, s. 131; Fâsî, Şifâu'l-Ğarâm bi-Ahbâri'l-Beledi'lHarâm, C. 2, Thk. Alî Ömer, Mektebetü's-Sekâfeti'd-Dîniyye, Kâhire 2008, s. 419.

${ }_{58}^{58}$ Berzâlî bu senenin Şaban ayının 12'sinde mahmilin dolaştığını kaydeder, Târihu 'l-Berzâlî, C. 2(1), s. 149.

${ }^{59}$ Fâsî, Şifâu'l-Ğarâm, C. 2, s. 420.

${ }^{60}$ İbn Fehd, İthâfü'l-Verâ, C. 3, s. 146; Cezîrî, ed-Dürer, C.1, s.389; Fâsî, Şifâu'l-Ğarâm, C. 2, s. 421; İbn Kesîr, elBidâye, C. 18, s. 98.

${ }^{61}$ İbn Fehd, İthâfü'l-Verâ, C. 3, s. 433; İbnü'l-Cezerî ise Dımaşk'tan bir kafile çıktığını, kafile'nin emîrinin etTanboğa el-Çobanî olduğunu, hac görevini ifa ettikten sonra ise Kâhire'ye döndüğünü kaydeder, Tarîhu İbni'lCezerî, C. 1, s. 419.

${ }^{62}$ Cezîrî, ed-Dürer, C. 1, s. 430; el-Fâsî, Şifâu'l-Ğarâm, C. 2, s. 432.

${ }^{63}$ İbn Fehd, Ithâfü'l-Verâ, C. 3, s. 349; Cezîrî, ed-Dürer, C. 1, s. 420.

${ }^{64}$ İbn Kâdı Şühbe, Tarihu İbn Kâdı Şühbe, C. 1, s. 163-164.
} 
Haleplilerin kendiliğinden oluşturduğu bir mahmil olduğu elbette düşünülemezdi. 1385 senesinde başlatılan Halep mahmilinin emîri ve görev tanımı, vazifeleri, sorumlulukları sultan tarafından tayin edilmiş ve bir mersûmla kendisine bildirilmişti. Buna göre mahmilin emîri olarak Şehâbeddîn Ahmed b. Tanboğa tayin edilmişti. ${ }^{65}$

Halep mahmili ve kafilesi, zaruri haller dışında düzenli olarak hacca gönderilen bir kafile değildi. İbn Kâdı Şühbe 1395/797 senesinde Sultan Berkuk (1390-1399) zamanında Dımaşk'a gelen ve buradan Mekke'ye giden Halep mahmilinin sarı rengi ve oldukça küçük oluşu ile dikkat çektiğini, yine bu mahmili tarif ederken de böyle bir olaya daha önce rastlanmadığını kaydeder. ${ }^{66} 3$ Kasım 1395/19 Muharrem 798 tarihinde, Halep kafilesi, ertesi günü de Dımaşk kafilesi Dımaşk'a varmışlar ve her iki kafile de normalden dört yahut beş gün önce giriş yapmışlardı. ${ }^{67}$ 1396/798 senesi Temmuz/Şevvâl ayında Halep kafilesi yanlarında mahmil olduğu halde Dımaşk'a giriş yapmıştı. Bu sene hac yapanların sayıları oldukça azdı. Ayın on dördünde Cuma günü, Cuma namazından sonra Dımaşk mahmili ve kafilesi Hicaz'a doğru yola çıktılar. Ancak bu daha önce tanık olunmuş bir şey değildi. Çünkü hem gün hem de saat olarak vakitsiz çıkmışlardı. Dımaşk mahmilinin hemen ardından da Halep mahmili yola çıkmıştı. ${ }^{68}$ 1398/800 senesinin Şevvâl ayı içinde Halepli hacılar Dımaşk'a gelmişlerdi. Ancak sayıları oldukça azdı. Üstelik onlar eskiden olduğu gibi yanlarında mahmil olmadan gelmişlerdi. ${ }^{69}$

1482/885 senesinde yine iki hac kafilesi çıkmıştı. Bu yıl Yelbay Devâdâr emîrliğindeki Dımaşk kafilesine katılım oldukça azken Şâfi Şemseddîn el-Kefersûsî’nin kadılık, Yusuf elHamzâvî’nin emîrlik yaptığı Halep kafilesinin sayısı oldukça fazlaydı. ${ }^{70}$

26 Ağustos 1490/9 Şevvâl 895 tarihinde Halep kafilesi beraberinde en az 4000 deve ve pek çok hayvan olduğu halde Dımaşk şehrine giriş yapmıştı. Kafile Halep’ten çıkarken ve yol boyunca askerlerin zulmüne maruz kalmış, kadınları taciz edilmiş, hacı adayları öldürülmüştü. $^{71}$

1465/869 senesinde ise Kerek'ten çıkartılan mahmilden ilk defa bahsedilerek Kereklilerin gayet latif bir mahmille hac yaptıkları kaydedilir. ${ }^{72}$ 1481/884 senesinde Sultan Kayıtbay'ın (1368-1496) haccı esnasında da bir defa daha Kerek mahmilinin varlığından bahsedilir. ${ }^{73}$

\section{Hac Emîrliği ve Hac Emîrlerinin Görevlerini Kötüye Kullanmaları}

Hac emîri en kısa ve sade tanımıyla hac kafilesinin haccın kurallarına uygun şekilde ve emniyet içinde, hac farizasını yerine getirmesinden mesul olan kişiye verilen unvandır. Hac emîrliğinin tarihçesi Mekke'nin fethine kadar uzanır. 630 yılında Hz. Peygamber Mekke'yi fethettikten sonra Attâb b. Esid Ebi'l-'Ays b. Umeyye'yi buraya vali olarak tayin etti ve Medine'ye geri döndü. Aynı yıl Attâb b. Esid Müslümanlara hac ibadetini yaptırdı. Ancak bir rivayete göre de o yıl insanlar başlarında hac emîri olmadan ibadetlerini yaptılar. Bir sonraki sene Hz. Peygamber, Hz. Ebû Bekir'i hac emîri olarak tayin etti. Böylece O, kesin olarak bilinen ilk hac emîri oldu. Ertesi yıl, Hz. Peygamber kendisi hac ettiği için kimseyi emîr olarak tayin etmedi. Onun vefatından sonra da hac farizasının güvenlik içinde yerine getirilmesi işi halifelerin ve sultanların görevlerinden sayıldı. Onlar da bu görevi ya kendileri yürüttüler ya da

\footnotetext{
${ }^{65}$ Kalkaşendî, Subhu'l-'Aşâ, C. 12, s. 435-436.

${ }^{66}$ İbn Kâdı Şühbe, Tarihu İbn Kâdı Şühbe, C. 1, s. 553.

${ }^{67}$ İbn Kâdı Şühbe, Tarihu İbn Kâdı Şühbe, C. 1, s. 572.

${ }^{68}$ İbn Kâdı Şühbe, Tarihu İbn Kâdı Şühbe, C. 1, s. 587.

${ }^{69}$ İbn Kâdı Şühbe, Tarihu İbn Kâdı Şühbe, C. 1, s. 660.

${ }^{70}$ İbn Tolun, Müfâkehetü'l-Hillân, s. 28; Cezîrî, ed-Dürer, C. 1, s. 473.

${ }^{71}$ İbn Tolun, Müfâkehetü'l-Hillân, s. 108.

${ }^{72}$ Cezîrî, ed-Dürer, C. 1, s. 466.

${ }^{73}$ Cezîrî, ed-Dürer, C. 1, s. 473.
} 
güvendikleri bir kişiyi görevlendirdiler. ${ }^{74}$ Hac emîrinin kafileyle ilgili başlıca sorumlulukları ise şunlardı: Hac kafilesinin toplu olarak yol almasını sağlamak, emniyetli ve suyun bol olduğu güzergâhı seçmek, hacılar arasındaki sorunları çözmek, haccın farz ve sünnetlerini eda ederken hacılara yardımc1 olmak. ${ }^{75}$ Hac emîrinin Mekke'deki görevi tevriye gününden bir gün önce başlar ve Mina'daki son gün güneş batıncaya kadar sürerdi. Bu zaman zarfinda gerek Mekke'de gerekse hac yerlerinde en büyük mülkî amir konumundayd1. Bu bakımdan hac süresince Mekke'nin emniyet ve asayişi başta olmak üzere bütün problemlerin çözümü emîr-i hac tayin edilen kişinin uhdesine verilirdi. ${ }^{76}$

Şâm kafilesinin hac emîri bizzat sultan tarafından tayin edilirdi. Buna göre Kâhire'den gönderilen mersûm Kâle'de resmî bir törenle okunur, "emîru'l-kâfile" yahut emîru'r-rekbi'şŞâmî" ünvanını kullanacak olan hac emîri açıklanır ve Dımaşk nâibi yeni tayin olunmuş hac emîrine hilatını giydirirdi. ${ }^{77}$

Görevi hacılara haccı emniyet içinde, rahat, tam ev eksiksiz olan, yol boyunca da her türlü yetkiye sahip olan hac emîrinin, atanmasında aranan temel özellikler olan "vakar, ciddiyet, heybet sahibi olmak, feraset sahibi olmak, emin ve şecaat sahibi olmak" ${ }^{, 78}$ şartlarına her zaman uymadıkları, bazı yılların hac emîrlerinin hacılardan ziyade kendi menfaatlerini gözettikleri, hacıların maslahatlarını ihmal ettikleri hatta maddi menfaat sebebiyle onlara zulmettikleri görülmektedir. Hac emîrleri bu neviden olumsuz tavırları sebebiyle hacılar tarafından şikâyet edilmişler, hac emîrleri de sultan tarafından bazen bir daha bu kutlu göreve tayin edilmeyerek bazen de fiziki olarak cezaya tabi tutulmuşlardır.

Örneğin; 5 Kasım 1297/18 Muharrem 697 tarihinde hacılar geri döndüklerinde, başlarındaki hac emîri Emîr 'İzzeddîn Aybek et-Tavîl'den şikayetçi oldular. Zira o, dönüş yolunda kafileyi acele ettirmiş, özellikle bineksiz hacılara sert ve kötü davranmış ve onun bu aceleciliği sebebiyle pek çok hacı vefat etmişti. ${ }^{79}$

1314/714 senesinde Gazzeli hacılar Dımaşk'a döndüklerinde, Misır hac emîri Balaban eşŞemsî’den şikâyetçi oldular ve Balaban bu şikâyet sonucu tutuklandı. Zira O, hacıların mallarına ve canlarına tamah etmiş, kötü ahlakını hacılara sert davranarak ortaya koymuştu. ${ }^{80}$

1371/773 senesinde hacılar Şâm Hac Emîri Akca b. el-Hemevî’yi yolculuk esnasındaki kötü tavırlarından dolayı Şâm nâibine şikayet ettiler. Nâib sikayetlere kayıtsız kalmadı ve hac emîrini cezalandırdı. el-Hemevî kendisine nâib tarafindan takdir edilen cezayı uyguladı, hamama girerek kendini hadım etti ve oracıkta bayılıp kaldı. Nâib onu bu halde görünce evine götürülmesini emretti. $\mathrm{O}$, bir müddet sonra sağlığına kavuştu. ${ }^{81}$

\footnotetext{
${ }^{74}$ Münir Atalar, "Emîr-i Hac", Türkiye Diyanet Vakfi İslâm Ansiklopedisi, TDV Yayınları, İstanbul 1995, C.11, s.131; Mehmet Erkal, "Hac Emîrliği (Yönetimi) ve Bununla İlgili Fikhi Meseleler", s.147-151; Burak Gani Erol, "Memlûkler Zamanında Misır Mahmili", s.63; Fatih Yahya Ayaz, Bahrî Memlukler Döneminde Harameyn Hizmetleri, (Marmara Üniversitesi Sosyal Bilimler Enstitüsü, Yüksek Lisans Tezi), İstanbul 1998, s. 26; Bedri Muhammed Fahd, "Hacc Emîrleri Tarihi”, Diyanet İlmi Dergi, Çev. Münir Atalar, S. 33/1, 1997, s. 38-39.

${ }^{75}$ Mehmet Erkal, "Hac Emîrliği (Yönetimi) ve Bununla İlgili Fıkhi Meseleler", s. 152-154; Fatih Yahya Ayaz, Bahrî Memlukler Döneminde Harameyn Hizmetleri, s. 28-29.

${ }^{76}$ Mustafa Sabri Küçükaşçı, Abbasiler'den Osmanlılar'a Mekke-Medine Tarihi, Yeditepe Yayınevi, İstanbul 2007, s.

272; Fatih Yahya Ayaz, "Bahrî Memlukler Döneminde Harameyn Hizmetleri”, s. 30.

${ }^{77}$ İbn Tolun, Müfâkehetü'l-Hillân, s. 128, 233.

78 Fatih Yahya Ayaz, "Bahrî Memlukler Döneminde Harameyn Hizmetleri”, s. 28-29; Mehmet Erkal, "Hac Emîrliği", s. 152.

${ }^{79}$ Cezîrî, ed-Dürer, C. 1, s. 385.

${ }^{80}$ Makrîzî̀, es-Sülûk, C. 2, s. 496.

${ }^{81}$ Cezîrî, ed-Dürer, C. 1, s. 416-417; İbn Hacer el-'Askalani, İnbâu'l-Ğumr, C. 1, s. 17.
} 
1403/805 senesinin Ramazan ayında ilginç bir hadise olmuş, Emîr Özbek er-Ramazânî, daha önceden hac emîri tayin olunmuş olan Emîr Baysak eş-Şeyhî’nin yerine bu göreve tayin olunmuştur. Görev değişikliğinin sebebi ise hacı adaylarının Emîr Baysak'a güvenmemeleriydi. ${ }^{82}$

1409/811 senesinde Misırl1 hacıların emîri Baysak, Halepli hacıların emîri Korkmaz'1 tutuklamıştı. Şâm'dan Korkmaz'ı kurtarmak üzere yardım gönderileceği düşüncesiyle de Mısır hacılarına Medine'yi ziyaret ettirmemiş, geri dönüş yolunda onları acele ettirmiş, sert davranmış ve hacılardan pek çoğu ölmüştü. ${ }^{83}$

1481/886 senesinin Nisan/Safer ayında hacılar Hicaz'dan Dımaşk'a döndüler. Hacılar bilahare Emevî Camisi'nde toplandılar ve hac emîri Yelbây'ın yol boyunca yaptığı zulümleri anlattılar. O özellikle kimsesizleri yakın takibine almış ve yolda öldükleri zaman miraslarına konmuştu. Akrabası olanlara da miraslarından pay vermemişti. ${ }^{84} 15$ Aralık 1489/21 Muharrem 895 tarihinde de Şâm kafilesi Dımaşk'a girdikten sonra kafiledekiler hac emîrinin adet üzere ona verilen deve ve sair hediyeleri almak için hacılara zulüm ettiğinden şikâyetçi oldular. ${ }^{85}$

\section{Hac Kafilesinin Güvenliği Nasıl Sağlanırdı}

"Hac kafilesi bir menzile (konağa) indiğinde yahut konaktan harekete geçtiğinde kafiledekileri uyarmak için davullar vurur, borazanlar üflenirdi. Böylelikle onların hazırlanması sağlanırdı. Zira geride kalan ya kaçırılır yahut ona eziyet edilirdi. Gece yahut gündüz yol alınırken kafilenin arkasından askerler yürürler böylece onları ve mallarını hırsız Araplar'dan yahut yol kesen eşkiyalardan korurlardı. Bir konağa indiklerinde, emîrler ve askerler baskınlara ve hırsızlara karşı müdebbir olurlardı. Emîrlerin çadırlarının önünde askerler meşaleler yakarak nöbet tutarlardı. Onlar yol alırken de atlı askerler yanlarında koruma maksadiyla refakat ederler, yaya müsellah askerler de inilen konakları kafileye duyururlardı. 'Urbânın topraklarından geçerken kafileye müteyakkız ve her an harekete hazır olmaları tenbih edilirdi. Böyle tehlikeli yerler kafilenin konaklaması için münasip değildi. 'Urbândan görülen olduğu vakit gören hemen kafileyi uyarırdı. Onlar tehlikelidirler ve kaçınmak gerekir. Ancak sultanlarımız bu 'Urbâna kafilenin geçişleri esnasında Mısır ve Şâm hazinelerinden muayyen miktarda ödeme yaparlardı. Misır ve Şâm mahmillerinin giderinden olmak kaydıyla nakdî ve kumaş cinsinden hediyeler ve şeyhleri içinde hil'atler senelik olarak kesintisiz gönderilirdi. 'Urbânın topraklarına varıldığında kabilenin şeyhleri mahmili karşılamak üzere çıkarlar, yeri öperler ve sultanın sancağına tabi olup altında yürürler, kafilenin güvenliğinin teminatı olarak da topraklarından çıkana kadar en yakın akrabalarını rehine olarak kafileye tabi kılarlardı. Kafile, topraklarını çıtıktan sonra bu rehineler serbest bırakı1ır ve de kendilerine getirilen hediyeler verilirdi. Rehinenin bulundurulma sebebi ise hacılardan zorla birşey alınma ve istenme ihtimaline karşılıktı. İşte bu sebepten topraklarından geçene kadar onlardan hiç kimse, hacılara eziyet etme yahut bir talepte bulunmaya cesaret edemezdi. Şayet olurda o bölgede meskûn olmayan Araplar kafileyi soyacak olurlarsa o bölgenin meskunları, bıraktıkları rehineler sebebiyle, onları izleyip çalınan malları geri alırlar yahut bedelini öderlerdi. Bu durum

\footnotetext{
82 İbn Kâd1 Şühbe, Tarihu İbn Kâdı Şühbe, C. 4, s. 308.

${ }^{83}$ İbn Hacer el-'Askalani, İnbâu'l-Ğumr, C. 2, s. 402.

${ }^{84}$ İbn Tolun, Müfâkehetü'l-Hillân, s. 32.

${ }^{85}$ Busrevî, 'Alâeddîn Alî b. Yûsuf b. Ahmed ed-Dımaşkî, Tarîhu'l-Busrevî, Thk. Ekrem Hasan el-'Ulebî, Dâu'lMe'mûn li’t-Turâs, Beyrut 1971, s. 140.
} 
pek çok kere vuku bulmuştur. Bu sayede hacılar kendilerinden ve mallarından son derece emin olurlard1." 86

el-Ömerînin de bahsettiği 'Urbân yani Çöl Arapları hac kafilesi için en büyük tehditti. Uzun hac yolculuğu esnasında Şâm hacılarının, diğer beldelerden yola çıkan hacı kafilelerinin karşılaştıklarına benzer, karşılaştıkları pek çok güçlük vardı. Bunlardan belki de en önemlisi, çöllerde meskûn Arap kabilelerinin, hacılara ve kafilelerine saldırması, mallarına ve canlarına kastetmeleriydi. Bankacılığın ve elektronik ödeme aletlerinin olmadığı zamanlarda hacılar, evlerinden çıkıp kafileye katıldıkları andan itibaren tekrar evlerine dönene kadar, yolculuk esnasında yapacakları tüm masrafı karşılayacak parayı, yolculuk esnasında kendilerine lazım olacak her türlü alet-edevat1, binek hayvanı, giyecekleri elbise vb. şeyleri yanlarında götürdükleri için, soyguncular için büyük bir nimettiler. Bu sebeple Arap kabileleri, kaynaklardan anlaşıldığı üzere, hac mevsiminin gelmesini iple çekerler, hacı adaylarının geçeceği yollara pusular kurarlar, hac kafilelerinin yollarını keserler ve onların mal ve canlarına tasallut ederlerdi. ${ }^{87}$

Dımaşk'tan yola çıkan mahmilin ve hac kafilesinin / kafilelerinin güvenliğini sağlamak maksadıyla kaç Memlûkün görevlendirildiğine dair kaynaklarda her y1la dair tafsilatlı bilgi bulunmamaktadır. Ancak Cezîrî, kafileyi korumakla görevli memlûklerin sayısının yirmiden az olmayacağını söyler. ${ }^{88}$ Cezerî ise Sultan el-Melikü'l-Mansûr Seyfeddîn Kalavun döneminden itibaren her sene tablhânât emîrinin, bütün masrafları beytü'l-mâl'dan karşıllanmak üzere beraberinde 120 askerle kafileye refakat ettiğini kaydeder. Ancak anlaşıldığ kadarıyla bu say1 ortalamayı ifade etmektedir. Örneğin; 1282/senesinde Dımaşk'tan Emîr Bedreddîn Güncük elHarezmî idaresinde oldukça kalabalık bir kafileyle hac edilmiştir. Güncük idaresindeki kafileye 150 memlûk koruma olarak refakat etmiştir. Emîr Güncük kendisiyle beraber kafileyi korumak maksadıyla asker götüren ilk emîrdir. ${ }^{89}$

Volume 12

Issue 4

August

12 Temmuz 1495/18 Şevvâl 900 tarihinde Şâm kafilesi Hicaz'a gitmek üzere yola koyulmuştu. Ancak bu sene Dımaşk ahalisinden bazı tüccarlar hariç hacca giden olmamıştı. Kafile Kuzey vilayetlerinden gelen hacılar ve Osmanlı hacılarından müteşekkildi. 200'den fazla tam donanımlı memlûk askeri de kafileyi korumakla mükelleftiler. ${ }^{90}$ Italyalı paralı bir asker olan Ludovico di Varthema, Nisan 1503 senesinde Avrupalı bir mühtedi olarak Yûnus adıyla hac kafilesinde yer almıştır. O, Íslâma ihtida etmiş eski bir arkadaşı tarafından, tıpkı bir memlûk gibi giydirilmiş, iyi bir ata bindirilmiş ve memlûklerin arasına karışarak Hacca gitmişti. Di Varthema 1503 senesine dair mufassal bilgi vermiş ve Şâm kafilesinde 40.000 deve, 35.000 hacı adayı olduğunu ve bunları korumakla görevli Memlûk askerlerinin sayısının ise kendisi ile birlikte altmış olduğunu söyler. Bu altmış Memlûk askeri kafile içindeki yirmisi kafilenin önünde, yirmisi ortasında ve yirmisi de sonunda olmak üzere konumlandırılmıştı. ${ }^{91}$

\footnotetext{
86 'Ömerî, Şehâbü'd-Dîn Ahmed b. Yahyâ, Mesâlikü'l-Ebsâr fî̀ Memâliki'l-Emsâr, C. 2, Thk. Kâmil Selmân elCubûrî, Mehdî en-Necm, Dâru'l-Kutubi'l-'Illmiyye, Lübnan 1971, s. 338-339; Burak Gani Erol, "Memlûkler Zamanında Misır Mahmili”, s. 70-71.

${ }^{87}$ Burak Gani Erol, "Memlûkler Zamanında Mısır Mahmili”, s. 71.

${ }^{88}$ Cezîrî, ed-Dürer, C. 1, s. 213-214.

${ }^{89}$ Berzâlî, Târihu'l-Berzâlî, C. 1(1), s. 538-539.

${ }^{90}$ Busrevî, Tarîhu'l-Busrevî, s. 164.

${ }^{91}$ Ludovico Di Varthema, The travels of Ludovico di Varthema in Egypty, Syria, Arabia Deserta and Arabia Felix, in Persia, India, and Ethiopia, A. D. 1503 to 1508, Çev. John Winter Jones, Neşr. G. P. Badger, The Hakluyt Sociesty, London 1863, s. 12-13; Ahmet Özel, "Hac (Seyahatnâmeler), Türkiye Diyanet Vakfi İslâm Ansiklopedisi, C. 14, TDV Yayınları, İstanbul 1995, s. 415-416.
} 


\section{Hac Kafilesinin Güvenlik Sorunu}

Uzun hac yolculuğu esnasında hacıların karşılaştıkları güçlüklerin başlıca geleni, Arapların saldırılarıydı. Özellikle devletin siyasî olarak güçten düştüğü dönemlerde (devletlerarası savaşlar, taht kavgaları, iktisadî krizler vs.) Arap kabileleri, hac kafilelerini kolay lokma olarak görmüşler ve baskınlar düzenlemişlerdir. Her ne kadar hac kafilesinin güvenliğini sağlamak üzere, sayısı yıldan yıla değişmekle birlikte, bir memlûk birliği kafileye eşlik etse de bazı yıllar bunun yeterli gelmediği, anlaşılmaktadır.

1283/681 senesinde Şâm Hac Emîri Bedreddîn es-Sevâbî, 'Şâm yolu üzerindeki Araplar'a topraklarından geçerken ve Hicaz ahalisine on bin dirheme baliğ parayı kendi cebinden vermiştir. Kendisinden her deve için 20 dirhem alınmıştır. $\mathrm{Bu}$ on bin dirhemin içinde hacılar adına verdiği 3 bin dirhem de vardır. Bu uygulama Sultan ez-Zâhir Baybars zamanından itibaren hep bu şekilde devam etmiştir. ${ }^{92}$

1350/751 senesinde Mekke'de şerîfler arasındaki rekabet esnasında Şâmlı hacıların da malları yağmalanmıştır. ${ }^{93}$ 1376/777 senesinde ise Mısır ve Şâm kafileleri dönüş yolunda Araplar tarafindan soyulmuştu. ${ }^{94}$

1401/803 senesinden 1404/806 senesine kadar Şâm hacıları, Timur tehdidi sebebiyle hacca gidememişlerdi. Timur 1401 senesinde Dımaşk'1 yakmış, yolların güvenliği kaybolmuş ve pek çok insan ölmüştü. ${ }^{95}$

1408/810 senesinde dönüş yolunda Kuzey Afrikalı hacılara Şâm hac kafilesi, Gazzeli, Kudüslü, İskenderiyeli hacılar da katılmışlar ve kafile yolda Araplar tarafından soyulmuştu. Özellikle Kuzey Afrikalı hacılar çok sıkıntı çekmişlerdi. ${ }^{96}$ 412/814 senesinde Şâm Hac Emîri Emîr Mü'min ve Araplar arasında Zeyza'da bir mücadele yaşanmış, hac emîri yaralanmış ve aldığ yara neticesinde vefat etmiştir. ${ }^{97}$

1437/841 senesinin hac dönüşünde Gazze kafilesine Remle, Kudüs ve diğer sahil şehirlerinin sakinleri ile Yenbu'lular da katılmıştı. Bu büyük kafilenin yolu Mekke'den çıktıktan sonra elEzlem $^{98}$ yakınlarında bulunan 'Anter Vadisi'nde Belî Kabilesi Araplarından kırk atlı ve yüz yirmi yaya asker tarafindan kesildi ve malları istendi. Kafilenin önde gelenleri Araplara istedikleri miktarda altın vererek yanlarından uzaklaşıp kafileye dâhil oldular. Ancak Gazzeli hacılar hem fikir değillerdi ve onlardan kafilenin önünde bulunanları Araplara ok atarak üç tanesini öldürdüler. Bunun üzerine Araplar kafileye saldırdılar ve kafilenin mallarına, develerine ve develerin taşıdığ 1 altın ve gümüşe, erzaka el koydular. El koydukları deve sayısı üç bin kadardı. Kafilede bulunanları acımasızca öldürdüler, esir aldılar. Bir kısmı yalın ayak ve çıplak kaçıp kurtulabilmişti ki onlar da bilahare öldüler. Daha sonra onlardan bir kısmı denizden ve karadan Kâhire'ye perişan bir vaziyette ulaştılar. Ama kadın erkek, kız, çocuk, çok insan ölmüştü. Ve devlet erkânından hiç kimse işlerini önemsememelerinden kaynaklı bu hadiseye aldırmadı bile. ${ }^{99}$ Ibn Hacer bu hadiseyi naklederken Belî Araplarına ilaveten Cüheyne Araplarının ve diğer kabilelerinde işin içinde olduklarından, kurtulabilenlerin çıplak olarak el-

\footnotetext{
${ }^{92}$ Cezîrî, ed-Dürer, C. 1, s. 381; İbnü'l-Cezerî, Tarîhu İbni'l-Cezerî, C. 1, s. 447.

${ }^{93}$ Makrîzî, es-Sülûk, C. 4, s. 118.

${ }^{94}$ İbn Hacer el-'Askalani, İnbâu'l-Ğumr, C. 1, s. 106-107.

${ }^{95}$ Cezîrî, ed-Dürer, C. 1, s. 428-429; İ̉n Fehd, İthâfü'l-Verâ, C. 3, s. 421; el-Fâsî, Şifâu'l-Ğarâm, C. 2, s. 432.

${ }^{96}$ Makrîzî, es-Sülûk, C. 6, s. 191.

${ }^{97}$ İbn Hacer el-'Askalani, İnbâu'l-Ğumr, C. 2, s. 493; İbn Fehd, İthâfü'l-Verâ, C. 3, s. 491.

${ }^{98}$ Kâhire ve Mekke arasında, hac yolculuğunun tam orta noktasına düşen bir menzil noktası, Kalkaşendî, Subhu'l'Aşâ, C. 14, s. 386.

99 Makrîzî, es-Sülûk, C. 7, s. 372-373; Ahmed er-Reşîdî, Hüsnü's-Safâ ve'l-İbtihâc bi-Zikri Men Vuliye İmâreti'lHâcc, Thk. Leylâ 'Abdüllâtif Ahmed, Mektebetü'l-Hânci bi-Mısr, Kâhire 1980, s. 143.
} 
Ezlem'e ulaştıklarını ve orada öldüklerini, o yılın hac emîri Akboğa et-Türkmani'nin o esnada el-Ezlem'de olduğunu ancak olayla ilgilenmediğini ve ertesi gün erkenden yola çıktığını belirtir. ${ }^{100}$

1462/866 senesinde Şâm kafilesi dönüş yolunda Merru'z-Zahrân Vadisi'nin yakınında elMevkide mevkiinde soygun girişimine maruz kalmıştı. Ancak eş-Şerîf Muhammed b. Berekât olayı işitir işitmez müdahale etmiş, 100 atlı göndererek Arapların elinden kafilenin mallarının çoğunu kurtarmaya muvaffak olmuştu. ${ }^{101} 1494 / 899$ senesinde Gazze kafilesi Hicaz'a kendi mahmilleri ile geldiler ve okçuları hem mahmili hem de hacıları sürekli olarak korudular. Bu sayede kafileden hiç kimse zarar görmedi. ${ }^{102}$

1494/899 senesinde Şâm hac kafilesinin emîri Erkmâs idi. Dönüş yolunda kafile 'Akabe'den çıkıp Ma'ân'a varmadan el-Hisâ' denilen yerde Araplar tarafından kuşatılmıştır. Araplar tüccarlardan bir kısmını tuttular. Tüccarlar kendilerini biner dinar vererek Araplardan kurtarmaya muvaffak oldular. Araplar her ne kadar kafiledekilere dokunmayıp kimseye zarar vermedilerse de kafiledekilerin tüm malları ellerinden gittiğinden onların tamamına yakını açlıktan, susuzluktan ve soğuktan ölmüştür. Ancak az bir kısmı Şevbek'e varabilmişlerdi. Kafilenin emîrinin Araplarla anlaşıp mallarına göz diktiği ve bu yüzden onun ve çevresindeki pek az kişinin Şâm'a varabildiği iddiaları ortaya atılmıştır. ${ }^{103}$ Araplar gasp ettikleri hacıları ve onlardan aldıklarını Ezre'ât'da pazarda satılığa çıkarmışlar, Dımaşk ahalisinden pek çok kimse hacıları ve mallarını satın almak için buraya gelmişlerdi. ${ }^{104}$

1499/904 senesinde hacılar dönüş yolunda iken Araplar el-Lecûn'da kafileye saldırmışlar, kafilenin üçte birini rehin almışlardı. Nâzırü'l-Ceyş'in ${ }^{105}$ dahi 50 devesini çalmışlardı. Hacılar kendilerini ve mallarını kurtarmak için Araplarla mücadeleye girişmişler ancak bilahare Beni Lâm kabilesinin reisi Ûmrân b. Mülâk'ın yardıma gelmesiyle kafileyi Arapların elinden kurtulmaya muvaffak olmuştu. ${ }^{106}$

1503/908 senesinde Di Varthema yolculuk esnasında uğradıkları bir saldırıdan da bahseder. Onun da içinde bulunduğu kafile Ürdün Vadisi'ni çıktıktan hemen sonra küçük bir dağın yamacında bulunan su kuyusunda durmuş ve geceyi orada geçirmişti. Ertesi gün sabah erken saatlerde Araplardan yirmi dört bin kişi gelmiş ve su için kendilerine ödeme yapılması gerektiğini söylemişlerdi. Kafileden "Allah'ın bahşettiği su için size ödeme yapmayacă̆ız" yanıtını aldıktan sonra ise "siz bizim suyumuzu aldınız" diyerek kavga münakaşa ve kavgaya başlamışlardı. Kafile hemen olası çatışmaya karşı hazırlık yapmış, Araplar ile aralarına kafiledeki develerden bir set oluşturmuş ve tüccarlar hemen bu seddin içine girmişlerdi. Akabinde çatışmalar başlamış ve kafile Araplar tarafından iki gün boyunca muhasaraya alınmıştı. Öyle ki her iki tarafında içme suları tükenme noktasına gelmişti. Yamacında su bulunan dağ tamamen Araplar tarafından kuşatılmıştı ve onlar sürekli olarak kafileyi zapt etmek ve soymaktan bahsediyorlard1. Kafile reisi (emîr) Kuzey Afrikalı tüccarlarla müşavere ettikten sonra Araplar'a bin iki yüz duka altın ödeme yapıldı. Ancak onlar, on bin duka altının bile sularının karşıllı̆̆ olamayacağını söyledikten sonra sadece para istemedikleri ortaya

\footnotetext{
100 İbn Hacer el-'Askalani, İnbâu'l-Ğumr, C. 4, s. 89-90; Makrîzî, es-Sülûk, C. 7, s. 372-373; Burak Gani Erol, "Memlûkler Zamanında Misır Mahmili", s. 74.

101 İbn Fehd, İthâfü'l-Verâ, C. 4, s. 432; Cezîrî, ed-Dürer, C. 1, s. 466.

${ }^{102}$ Cezîrî, ed-Dürer, C.1, s. 480.

${ }^{103}$ Cezîrî, ed-Dürer, C. 1, s. 480; İbn Tolun, Müfâkehetü'l-Hillân, s. 132-133.

${ }^{104}$ Busrevî, Tarîhu'l-Busrevî, s. 153, 156-157; Cezîrî, ed-Dürer, C. 1, s. 480.

105 Memâlikü's-Sultâniyye'nin kayıtları, teçhizleri ve maaşlarının verilmesi ile Mısır ve Suriye'deki bütün askerî iktaların işleriyle uğraşan görevlidir, İsmail Hakkı Uzunçarşılı, Osmanlı Devleti Teşkilatına Medhal, s. 369-370; Altan Çetin, Memlûk Devletinde Askerî Teşkilât, s. 62-63.

${ }^{106}$ Busrevî, Tarîhu'l-Busrevî, s. 223-224.
} 
çıkmıştı. Tedbiri elden bırakmayan kafile reisi, kafileyi hazırlamış, eli silah tutanlar erkekler de develerinden inerek silahlarını kuşanmışlardı. Ertesi sabah kafile yola koyulmuş, Memlûkler ve diğer silah kullanabilecek olan erkekler ki iki yüz kırk kişi oldukları anlaşılıyor, geriden kafileyi takip etmişlerdi. Arapların kafileye saldırısı sonucu meydana gelen mücadele de kafileden bir kadın ve bir erkek attıkları oklar sonucu ölmüş, bunun haricinde zarar gören olmamıştı. Ama Araplardan ölenlerin sayısı bin altı yüz kişiydi. Toplam üç yüz kişinin, altmışı memlûk olmak üzere, bu kadar çok kişiyi öldürebilmelerinin sebebi ise onların tamamen çıplak, zırhsız ve atlarının eyersiz olması sebebiyle kontrollerinin zayıf olmasindan kaynaklanmaktaydı. ${ }^{107}$ Yine aynı y11 9 Ağustos 1502/4 Safer 908 tarihinde Dımaşk'a hacılar ile ilgili haber geldi. Buna göre Mekke Şerifi'nin kardeşi Câzân, Mekke'nin girişinde Misır kafilesinin önünü keserek onlardan para ve mal istemiş ancak Misır kafilesinin hac emîri onu oyuna getirerek sağ salim Mekke'ye girmeyi başarmıştı. Câzân bundan sonra Şâm kafilesinin yolunu kesti ve onlardan taleplerde bulundu. Kafile kendilerinden isteneni veremeyince Mekke girişinde gasp edildi. ${ }^{108}$

1507/912 senesinden 1511/ 916 senesine kadar dört sene müddetle dâhili sorunlar sebebiyle Şâm hac yolu üzerinden hac yapılamamıştı. Ancak 1511 senesinde münadiler hacca gideceklerin hazırlanmasını, hac zamanı gelince kafilenin çıkacağını ilan ettiler. Emîr Esbay hac emîri tayin edildi. Şâm'dan hac kafilesi gideceğine Dımaşk halkı ve esnafı da çok sevinmişti. Zira haccın iptal olunduğu senelerde şehirde hac ekonomisi de çökmüş, pek çok şeyin üretimi durma noktasına gelmişti. Hac kafilesi hazırlandıktan sonra yola çıktı. Ancak kafile yol boyunca Arapların tehlikesinden dolayı Tebük yolunu değil, Gazze yolunu takiple Hicaz'a gitti. ${ }^{109}$

1519/924 senesinde hacılar dönüş yolunda iken Âlu Dağîm Arapları Tebük'ten hareket ettikten sonra Mekâbirü'l-Kalenderiyye yakınlarında kafileyi durdurmuşlar, hacılar ve Uhayder arasına girmişler ve kafileye saldırmışlardı. Bütün gün süren mücadele neticesinde kafile savaşı kazanmış hatta Arapların liderlerinden 3 tanesini ve çok sayıda da atı ele geçirmeye muvaffak olmuştu. Hacıların kazanmasındaki en büyük sebep yanlarında ateşli silah olarak 100 tane tüfek olmasındandı. Kafile mücadeleden sonra Sonra Uhayder'e sağ salim ulaştıla. Dımaşk’ta müjde davullar1 vuruldu. ${ }^{110}$

\section{Tabiat Hadiselerinin Hac Üzerine Etkisi}

Kıtlık/kuraklık ve bunlarla beraber ortaya çıkan fiyat hareketleri, sıcak hava, kar, soğuk ve sıcak (çöl) rüzgârları bazı yıllar hac vazifesinin yapılamamasında ve de sair yıllarda da hacı adaylarının önündeki en büyük engellerden birisiydi. Bu tabiat hadiseleri de en az hac yolunun güvenliği kadar önemliydi.

Örneğin; 1305/704 senesinde hacılar yolları boyunca susuzluk, kıtlık, fiyatların yüksekliği, aşırı sıcak gibi zorluklara duçar olmuşlar, kurumuş su kaynaklarının yanında pek çok hacı vefat etmişti. Hacılar kuraklıktan kaçmak için en-Nâr Vadisi yerine başka bir yola sapmışlar ve bu yolda da pek çoğu ölmüştü. ${ }^{111}$

1346 / 746 senesinde havaların kurak gitmesi önceleri herkesi endişelendirip pek çok kişiyi hacca gitmekten dahi men ettiyse de bilahare yağan yağmur herkesi ferahlatmıştı. Ancak bu

\footnotetext{
${ }^{107}$ Ludovico Di Varthema, The Travels of Ludovico di Varthema, s. 14; Burak Gani Erol, "Memlûkler Zamanında Misir Mahmili", s. 72.

${ }^{108}$ İbn Tolun, Müfâkehetü'l-Hillân, s. 211.

${ }^{109}$ İbn Tolun, Müfâkehetü'l-Hillân, s. 276.

${ }^{110}$ İbn Tolun, Müfâkehetü'l-Hillân, s. 387.

${ }^{111}$ Makrîzî, es-Sülûk, C. 2, s. 383
} 
sene hac kafilesi es-Sanemeyn'de şiddetli bir yağmura yakalanmış ve bu sebeple burada günlerce kalmışlardı. Kafile bilahare yola devam ettiğinde ise Zura' mevkiine varamadan tekrar şiddetli bir yağmura yakalanmış, hacıların pek çoğu geri dönmek zorunda kalmıştı. Kafiledeki kadınların Zura' ve es-Sanemeyn arasında çıplak ayak yürümekten ayakları uyuşmuş ancak Busrâ'ya vardıklarında rahata ermişlerdi. ${ }^{112}$

1399/801 senesinde ilginç bir hadise olmuş, hacılar yiyip içip istirahat ettikten sonra yürümeye devam etmişler ve sonrasında yere düşüp çırpınarak ölmüşlerdi. en-Nâr Vadisi'nde, Râbiğ'de, Haremeyn'de bu şekilde pek çok hacı hayatını kaybetmişti. Bunun sebebinin şiddetli sicak olmasi muhtemeldir. ${ }^{113} 1423 / 827$ senesinde, Şâm hac kafilesi dönüş yolunda sicak ve rüzgar sebebiyle Bilâdu Hevran' da ${ }^{114}$ büyük zorluklara duçar olmuş, Dımaşk naibi Tönbek elBecâsî, onlara erzak takviyesi yapmıştı. ${ }^{115}$

1493/898 senesinde Şâm ve Halep hacıları iki ayrı grup olarak hacca gitmişlerdir. Halep kafilesi Râşide yolunu takip ederek gittiğinden su sıkıntısı çekmemişti. Ancak Şam hacıları mutat güzergâhı takip ettiklerinden susuzluktan mustarip olmuşlardı. Aynı yıl Mekke'de yiyecek sıkıntısı vardı ve sıcak çok fazla olmuş, hacılar gündüz sıcağının şiddetinden büyük 1stırap çekmişler ve bir kısmı da vefat etmişti. ${ }^{116}$

22 Haziran 1505/19 Muharrem 911 tarihinde Dımaşk'a gelen haberde hacıların büyük zorluk çektikleri yazmaktaydı. Hacılar 16 gün Mekke'de, 1 hafta Medine de, Sahra'da ise 13 gün geçirmişlerdi. Hacılar el-Ganâim Vadisi'nde ve Huley’te şiddetli bir rüzgâra yakalanmışlar ve pek çok hacı ölmüştü. ${ }^{117}$

\section{2. Şâm Hac Yolu}

Dünyanın çeşitli yerlerinden kutsal topraklara ulaşmaya çalışan hacıların dört ana güzergâhından birisi olan Şâm yolu hususî öneme sahip yollardan birisiydi. Bu yolun en önemli şehri ise kuşkusuz Dımaşk idi. Memlûk Devleti'nin temelini oluşturan iki büyük merkezden birisi olan ve Şâm'ın merkezi konumundaki Dımaşk şehri, siyasî, iktisadî ve askerî öneminin yanı sıra, Kâhire'den sonra mahmil törenlerinin yapıldığı ikinci merkez ve Arap, Türk, Moğol ve İran hacılarının toplanma merkeziydi. Dımaşk merkezli Şâm hac yolu İslamiyet'in ilk dönemlerinden itibaren oldukça önemli olup her dönem ilgi ve ihtimam gösterilmiştir.

Kureyş kabilesi tarafından Yemen ve Şâm arasında ticaret maksadıyla kullanılan yollardan olan Şâm yolundan Kuran-1 Kerîm'de Kureyş Suresi'nin birinci ve ikinci ayetlerinde bahsedilmekte ve "Li' î lâfi Kurayş̧ 'in, Îlâfihim Rihleteşşitâi Vessayf" denilerek bu yola vurgu yapılmaktadır. Ayet-i Kerîme'de "Şitâ"” kelimesi ile kışın Yemen'e, "Sayf" kelimesi ile de yazın bu bölgeye yapılan ticarî yolculuklardan bahsedilmektedir. ${ }^{118}$ Kafileler Hicaz'dan Şâm'a giderken başlıca iki güzergâhı kullanmaktaydılar. Bunlardan birisi Medîne - Tebük - Busrâ ve

\footnotetext{
112 İbn Kâdı Şühbe, Tarihu İbn Kâdı Şühbe, C. 2, s. 451; İbn Kesîr, el-Bidâye, C. 18, s. 482-483.

${ }^{113}$ İbn Kâdı Şühbe, Tarihu İbn Kâdı Şühbe, C. 4, s. 65; İbn Hacer el-'Askalani, İnbâu'l-Ğumr, C. 2, s. 92; Cezîrî, edDürer, C. 1, s. 428.

${ }^{114}$ Dımaşk'ın güney sınırından başlayıp Busrâ'yı da içine alan, oldukça geniş bir sahayı ve pek çok köye havi bölge, Yakut el-Hamavî, Ebû 'Abdillâh Şihâbiddîn Yakut b. 'Abdillâh, Mu'cemu'l-Buldân, C. 2, Dâru Sâdır, Beyrut 1977, s. 317.

${ }^{115}$ Cezîrî, ed-Dürer, C. 1, s. 442; İbn Hacer el-'Askalani, Inbâu'l-Ğumr, C. 3, s. 334.

116 İbn Tolun, Müfâkehetü'l-Hillân, s. 126-127.

117 İbn Tolun, Müfâkehetü'l-Hillân, s. 234.

${ }^{118}$ https://kuran.diyanet.gov.tr/tefsir/Kureyș-suresi/6194/1-4-ayet-tefsiri; $\quad$ Muhammed Hamidullah, "Hz. Peygamber'in İslâm Öncesi Seyahatleri”, Terc. Abdullah Aydınlı, Atatürk Üniversitesi İslamî İlimler Fakültesi Dergisi, S. 4, 1980, s. 328; Emin Işık, "Kureyş Sûresi Üzerine Bir Tefsir Denemesi”, Marmara Üniversitesi İlahiyat Fakültesi Dergisi, S. 3, 1995, s. 11.
} 
Dımaşk ana eksenli Tebük yoludur. Hz. Peygamber amcası Ebû Tâlib ile Hz. Hatice adına Şâm'a ticaret yaparken bu yolu kullanmıştır. ${ }^{119}$ İslâm orduları da Yezid b. Ebî Süfyân ve Ebû Ubeyde b. Cerrâh ve Şurahbîl b. Hasene idaresinde Şâm şehirlerini fethederken bu yolu kullanmışlardır. ${ }^{120}$ Diğer yol ise Kızıl Deniz sahili yolunun takip edildiği Gazze - 'Akabe eksenli Mu'rika olarak da maruf güzergâhtır. Bu güzergâh Kureyş kabilesinin Şâm'a giderken kullandığ1 yollardan birisiydi. Hz. Peygamber'in büyük dedesi ve Benî Hâşim'in atası olan Hâş̧im b. 'Abdümenâf'ta bu yolu kullanarak gittiği Gazze'de vefat etmiş ve burada gömülmüştür. ${ }^{121} \mathrm{~Hz}$. Ömer Selmân'a bir seferinde "Medîne yahut Mu'rika yolunu mu kullanacaksın?" diye sorarak bu yolu kastedmişti. ${ }^{122}$ Gazze yolu Memlûkler döneminde ana güzergâh olarak kullanılmamış, Tebük yolunun kullanılamadığı zamanlarda alternatif yol olarak tercih edilmiştir. Şâm ve Şâm üzerinden hacca giden hacıların sürekli kullandıkları Tebük yolu ve menzilleri, Haçlı seferleri tehdidi sebebiyle inkıtaya uğradığı yaklaşık 200 yıllık süre haricinde sürekli olarak açık kalmıştır. ${ }^{123}$

\section{Tebük Yolu ve Menzilleri}

Şâm hac kafilesi genellikle Şevvâl ayının 15'inde hac emîrinin riyaseti altında, 728 mil, 242 fersah $^{124}$ sürecek olan kutsal yolculuğuna ${ }^{125}$, yolculuğun başlangıç noktası olarak kabul edilen Kubbetü'l-Hacc' dan hareketle başlard ${ }_{1}{ }^{126}$ Buradan sonra kafile yolculuğun ilk menzili ve tüm hacıların toplanma merkezi olan Kusve'ye varırd. ${ }^{127}$ Geniş bir ova olan ve bir akarsuyun bulunduğu Kusve'de kafile bir ya da iki gün kalır ${ }^{128}$ ardından Dımaşk'a uzaklığı altı fersah olan ve Bilâdu Hevrân'ın ilk köyü olan Sanmeyn'e giderdi. ${ }^{129}$ Sanmeyn'den Bilâdu Hevrân'ın küçük köylerinden olan ve Dımaşk'a uzaklığı yaklaşık 3 merhale $^{130}$ olan Zere' ya ${ }^{131}$ varılırdı. Kafile Zere'da iki gün kaldıktan sonra 3 merhale uzaklıktaki Busrâ'ya gider ve Dımaşk'ta hazırlıklarını tamamlayamadığı için kafileye yetişemeyenleri beklemek maksadıyla Busrâ'da 3 yahut 4 gün kalırdı. ${ }^{132} \mathrm{~Hz}$. Peygamber, peygamber olmadan önce Hz. Hatice'nin sermayesi ile ticaret yapmak için bu beldeye gelmişti. Busrâ'da Hz. Peygamber'in devesinin çöktüğü yerde

\footnotetext{
${ }^{119}$ Muhammed Hamidullah, "Hz. Peygamber'in İslâm Öncesi Seyahatleri”, s. 331-332.

${ }^{120}$ Belazuri, Ahmed b. Yahya, Fütûhu'l-Buldân, Terc. Mustafa Fayda, Siyer Yayınları, İstanbul 2013, s. 127-128; İsrafil Balc1, "Şam Bölgesi Fetihleri", İslâm Tarihi ve Medeniyeti, C.2, Siyer Yayınları, İstanbul 2018, s. 173-175.

121 İbrahim Sarıçam, "Hâşim b. Abdümenâf", Türkiye Diyanet Vakfi İslâm Ansiklopedisi, C.16, TDV Yayınları, İstanbul 1997, s. 405-406.

${ }^{122}$ Yakut el-Hamavî, Mu'cemu'l-Buldân, C. 5, s. 155.

${ }^{123}$ Makrîzî, Takiyyü'd-Dîn Ahmed b. 'Ali, el-Mevâ'izü'l-İ'tibâr bi-Zikri'l-Hitat ve'l-Asâr, C. 1, Thk. Muhammed Zeynuhum - Medîha eş-Şerkâvî, Mektebetü Medbûlâ, Kâhire 1998, s. 566-567.

${ }^{124} 1$ fersah yaklaşı 3 mil olup bu da yaklaşık olarak 6 km.ye tekabül etmektedir, Yusuf Halaçoğlu, "Fersah", Türkiye Diyanet Vakfi İslâm Ansiklopedisi, C. 12, TDV Yayınları, İstanbul 1995, s. 412.

${ }^{125}$ Cezîrî, ed-Dürer, C. 2, s. 47

${ }^{126}$ Eyüp Sabrî Paşa, Mir'âtü'l-Cezîreti'l- 'Arab, thk. Ahmed Fu'ad Mütevellî, es-Safsâfî Ahmed el-Mursî, Dâru'lÂfaki'l-'Arabiyye, Kâhire 1999, s. 171.

${ }^{127}$ Yakut el-Hamavî, Mu'cemu'l-Buldân, C. 4, s. 461; İbn Battuta, Ebû 'Abdullah Muhammed et-Tancî, İbn Battûta Seyahatnâmesi, Çev. A. Sait Aykut, Yapı Kredi Yayınları, İstanbul 2013, s. 117; Eyüp Sabri Paşa, Mir'âtü’lCezireti'l-'Arab, s. 171.

128 'Ömerî, Mesâlikü'l-Ebsâr, C. 2, s. 343; Cezîrî, ed-Dürer, C. 2, s. 58

${ }^{129}$ Cezîrî, ed-Dürer, C. 2, s. 58; İbn Battuta, Seyahatnâme, s. 117.

${ }^{130}$ Merhale bir yolcunun normal yürüyüşle bir günde, ortalama 8 saat yolculuk yapmak suretiyle, gidebileceği uzaklık için kullanılan bir tabir olup, konak ile aynı anlama gelmektedir. 1 merhale 8 fersaha yahut 24 mile tekabül etmektedir, Cemal Çetin, “Osmanlılarda Mesafe Ölçümü ve Tarihî Süreci”, Prof. Dr. Nejat Göyünç Armăganı, Ed. Hasan Bahar vd., Türkiyat Araştırmaları Enstitüsü, Konya 2013, s. 454.

${ }^{131}$ Eyüp Sabri Paşa buranın adını Ezreğât olarak kaydeder, Mir'âtü'l-Cezireti'l- 'Arab, s. 171.

132 'Ömerî, Mesâlikü'l-Ebsâr, C. 2, s. 343; Cezîrî, ed-Dürer, C. 2, s. 59.
} 
büyük bir mescit inşa edilmişti. Hevrân ahalisi Busrâ'da toplanır, hacılar da buradan ihtiyaçlarını temin ederlerdi. ${ }^{133}$

Busrâ'dan kalkan kafilenin bir sonraki durağı uzaklığı 2 merhale olan Zîzấ' / ez-Zurkâ'dır. İçme suyu ihtiyacının suyu gür bir akarsudan karşılandığı Zîzâ' çok sayıda hurma bahçesi vardır. ${ }^{134}$ Burada bir yahut iki gün kalındıktan sonra yola devam edilir ve 2 merhale daha gidildikten sonra kafilenin üç yahut dört gün kaldığı $Z$ Zirâ'ya ulaşılırdı. ${ }^{135}$ Zîrâ'dan yola devam edilir ve Kerek yakınlarında büyük bir köy olan ve yanında bir akarsuyun bulunduğu elLeccûn'a varılırdı. el-Leccûn'dan 5 merhale gidildikten sonra Hısnu Ğurâb (Karga Kalesi) olarak maruf Kerek'e vasıl olunur ve üç yahut dört gün es-Seniyye denilen yerde kalınırdı. ${ }^{136}$ Kerek, bütün vadiyi kontrol altında tutan, her köşesinden derelerin aktı̆̆ oldukça büyük ve kalesi ile meşhur bir kentti. Taşlar delinerek yapılmış tek bir kapısı vardı. Bu kapıdan geçtikten sonra yine kayalara oyulmuş uzun bir dehlizden geçilerek şehre giriş yapılırdı. ${ }^{137}$ Kerek ekili dikili münbit arazilere sahipti. ${ }^{138}$ Kerek'ten sonra 2 merhale gidilerek el-Hisấ ya ulaş1lırdı. elHisâ ve sonrasındaki yerleşim yerleri kendisinden öncekilere hiç benzemezdiler. Çünkü öncesindekilerin her birisi mamur beldeler olup içime elverişli suları, çarşıları, pazarları bulunurdu. ${ }^{139}$ el-Hisâ'dan sonra 2 merhale kat edilerek Ma'an'a varılır ve burada üç gün kalınırdı. ${ }^{140}$ Ma'an, Şâm'ın son, Hicaz'ın ilk şehri olması bakımından önemliydi. Her türlü gıda maddesinin temin edilebildiği mühim bir çarşısı vard. ${ }^{141}$ Lakin suları çok iyi değildi ve ancak mecbur kalınırsa içilirdi. ${ }^{142}$ Ma'an'dan 3 merhale yahut 2 gün sonra suyun bulunmadığ 'Akabetü's-Savân'a varılırdı. ${ }^{143}$ Ma'an ve 'Akabetü's-Savvân arası çöl olup burası hakkında "giren rahmetli, çıkan devletli" diye bir söz vardır. Oldukça meyilli ve engebeli bir yapısı olduğundan hacılar burada büyük güçlük çekerlerdi. Su olanakları da oldukça kısıtlıydı. ${ }^{144}$ Çölden 2 merhale sonra kafile Zâtu Hacc mevkisine ulaşırdı. ${ }^{145}$ Zâtu Hacc çevresine göre aşağıda kalan, her hangi bir yerleşimin olmadığı bir mevki idi. Ancak suyu oldukça tatlıydı. ${ }^{146}$ Yoluna devam eden kafile hiç su bulunmayan Beldah Vadisi'ne ve ardından da uzaklığı Zatu Hacc'a 4 merhale olan ve Hz. Peygamber'in gazada bulunduğu Tebük'e varırdı. Rivayete göre, Tebük'te görülen bir kaynağın suyu daha önce gayet zayıfmış, ipil ipil akarmış. Hz. Peygamber burada abdest aldıktan sonra suyu gürleşmiş ve halen de aynı şekilde akmaktadır. Hacı kafilesi Tebük'e varınca silahlarını kuşanır, kılıçlarını sıyırır ve hamle edercesine yürüyerek hurma dallarına kılıçlarını sallarlardı. Bu esnada da "Peygamberimiz bu şehre böyle girdi" derlerdi. Kafile Tebük'te bulunan su kaynağında mola verirdi. Herkes kana kana su içer, develerini sularlardı. Sucular bu kaynağın etrafına inerek manda derisinden yapılmış büyük tulumlarıyla develerini sularlar, diğer kaplarını doldururlardı. Emîrlerden yahut büyüklerden her birinin kendine ait bir tulumu vardı. O tulumla hem develerine hem de arkadaşlarınınkilere su getirir; kap kacak ne varsa doldururlardı. Diğer hacılar ise birkaç dirhem karşıllğında kendi devesini

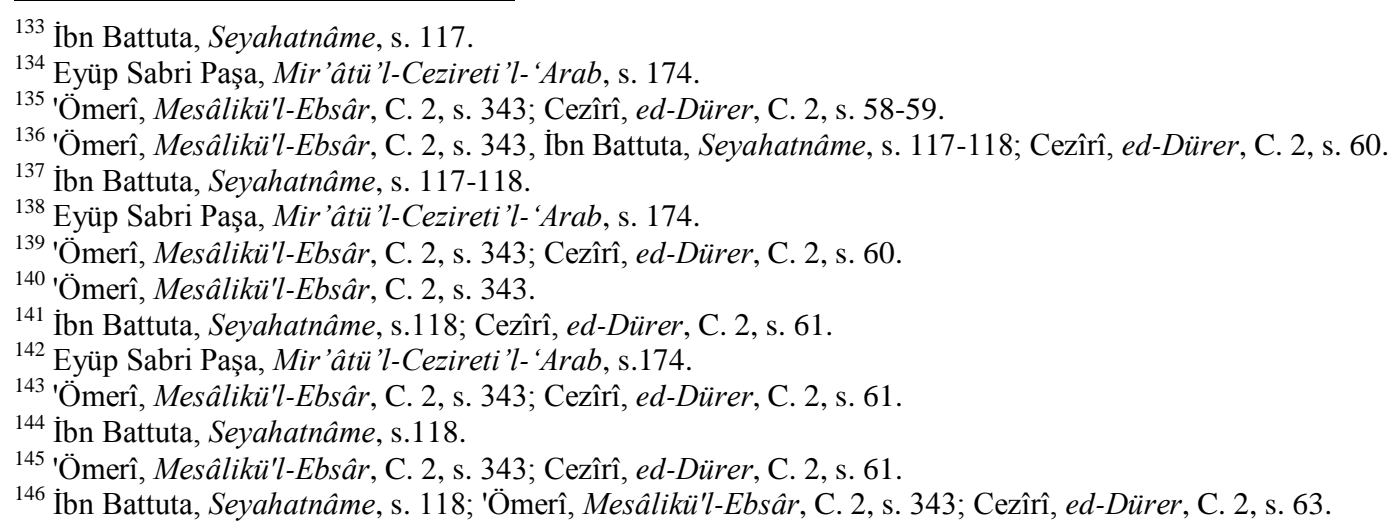


sulamak ve kırbasını doldurmak üzere orada çalışan sucularla anlaşır. ${ }^{147}$ Burada bir gün / dört gün ${ }^{148}$ kalınır ve arkasından başlayan çöl için hazırlık yapılırdı. Tebük’te su bulunmakla birlikte bu su bozulmaya oldukça müsaitti. Taşıma esnasında süratle kokusu ve tadı değişirdi. Ayrıca az miktarda da hurma ağacı bulunurdu. Hacılar burada alışveriş yaparlardı. ${ }^{149} 1330 / 731$ senesinde Şâm Nâibi Tengiz, Şâm hac yolunu 1slah edip genişletirken buradaki kaynağını da genişletip 1slah etmiştir. ${ }^{150}$ Eski adı el-Eyke olan Tebük'ün Hz. Şu'ayb'ın peygamber olarak gönderildiği Medyen ile aynı yer olduğu söylenildiği gibi, aynı halka sahip olan ve karşı karşıya bakan iki şehir olduğuna dair rivayetler de vardır. ${ }^{151}$

Hac kafilesi Tebük'ten sonra büyük bir çöle girer, korkarak gece gündüz ilerler ve Hicaz'ın büyük şehirlerinden olan $e l$ - 'Ulâ'ya giderdi. Tebük'ten el-'Ulâ'ya gidilirken ikisinin ortasında yer alan el-Uheyder Vadisi'ne kadar hiç su bulunmazdı. el-Uheyder'de suyu tüm hacıların ihtiyacını karşılamaya yeterli olmayan ve vadinin ismi ile birlikte anılan, ağzı kova girmeyecek kadar dar bir kuyu bulunurdu. Bu güzergâhı kullanan Şâm tüccarları kuyuyu 1slah etmek için gayret ettilerse de başarılı olamamışlardı. Buranın suyu yağmur sularının birikmesiyle oluşan havuzlardan ibarettir. Bu sular da hacıların kısmetine bazen bulunur bazen bulunmazd1. ${ }^{152} 1372$ senesinde Şâm hacıları dönüş yolunda el-Uheyder'de şiddetli bir kuraklık ve susuzluğa yakalanmışlar ve pek çok kişi ölmüştü. Bunun sebebi ise şuydu: Kafile giderken uğradığı elUheyder'de konakladığında hac emîri buradaki suyun azlığından mütevellit görevlilere artezyen vurdurup havuzlara doldurtmuş, hacılara bolca su sağlamıştı. Dönüşte de hacılar, aynı giderken olduğu gibi burada bol su olduğunu düşünüp tedbirsiz gelmişler, yol boyunca yanlarındaki suyu bol kullanıp birbirlerine ikram etmişler hatta develere bile kendi sularından içirmişlerdi. Ama buraya geldiklerinde ne artezyenlerin kaldığını, ne havuzlarda suyun olduğunu ne de kuyuda su bulunmadığını görünce, kuyu başında susuzluktan ve sıcaktan pek çoğu ölmüştü. ${ }^{153}$

İbn Battuta Tebük ve el-'Ulâ arasındaki çölü şöyle tarif eder: “Kervan hareket ederek bahsettiğimiz tehlikeli çölden gece gündüz yoluna devam eder. Sahranın tam ortasinda cehennem vadisine benzeyen el-Uhaydır adinda bir çukur vardır. Geçmis yilların birinde suların semûm (sam) yeliyle kuruyup bir kırbasının 1000 dinara satıldiğı, fakat suyu satanın da alanin da helak olduğu, vadide dikili bir taşta yazllıdır. Daha sonra Eyyûbîlerden Melik Muazzam'a (İsâ b. el-'Âdil Eb̂̂ Bekir b. Eyyüb b. Şâzî) (ö. 624) nispet edilen Birketü'lMuazzam'a inilir. Orada bazen yağmur iyi yağar, su birikir; bazen de kuraklık her tarafı kırar geçirir." ${ }^{154}$ Kafile el-'Ulâ'ya gelmeden yarım gün önce Semûd kavmiyle ilgili meşhur Hicr Kuyusu'na gelirdi. Bu kuyunun suyu gürdür ama Hz. Peygamber Tebük Savaşı'nda buradan geçerken devesini hızlandırarak kimsenin o kuyudan içmemesini emrettiğinden dolayı, çok susamış olsalar bile hacılar bu kuyudan su içmez, kim bu suyla hamur yoğurmuşsa kendi yemez, devesine yedirirdi. Burası Semûd kavminin şehridir. Bu kavim, kırmızı kayalık dağların böğrüne evler oymuştur. Eşikleri nakışlarla süslü, uzaktan görenler, buraların henüz yapıldığını zanneder. Bu kavmin çürümüş kemiklerini evlerde görmek mümkündür. Sâlih Peygamber’in

\footnotetext{
${ }^{147}$ İbn Battuta, Seyahatnâme, s. 118-119.

148 İbn Battuta, Seyahatnâme, s. 118.

149 'Ömerî, Mesâlikü'l-Ebsâr, C. 2, s. 343; Cezîrî, ed-Dürer, C. 2, s. 61.

150 İbnü'l-Cezerî, Tarîhu İbni'l-Cezerî, C. 2, s. 465; İbn Kesîr, el-Bidâye, C. 18, s. 333.

${ }^{151}$ Yakut el-Hamavî, Mu'cemu'l-Buldân, C. 1, s. 291; Cüneyt Eren-Muharrem Y1ldız, "Kur'an-1 Kerim ve Kitâb-1 Mukaddes'te Şuayb Aleyhisselam”, Dinbilimleri Akademik Araştırma Dergisi, S. 2, 2002, s. 111.

${ }^{152}$ İbn Battuta, Seyahatnâme, s. 119; 'Ömerî, Mesâlikü'l-Ebsâr, C. 2, s. 344; Eyüp Sabri Paşa, Mir'âtü'l-Cezireti'l'Arab, s. 174.

${ }^{153}$ İbn Hacer el-'Askalani, İnbâu'l-Ğumr, C. 1, s. 33.

${ }^{154}$ İbn Battuta, Seyahatnâme, s. 119; 'Ömerî, Mesâlikü'l-Ebsâr, C. 2, s. 344; Eyüp Sabri Paşa, Mir'âtü'l-Cezireti'l'Arab, s. 176.
} 
devesinin çöktüğü yer dahi orada iki dağ arasındadır. Civarda bir mescit kalıntısı vardır. Halk orada namaz k1lar. ${ }^{155}$ Hicr Kuyusu'ndan bir sonraki menzil el-'Ulâ ise yaklaşık yarım merhaledir. ${ }^{156}$

Tebük ve el-'Ulâ'ya arasındaki mesafe İbn Battuta'ya göre 6 gün, Ömerî ve Cezîrî’ye göre ise yaklaşık 12 merhale ${ }^{157}$ kadardır. el-'Ulâ büyük ve güzel bir kasaba olup akar suyun olduğu, hurmalık, bahçelik bir yerdir. Halkı iyi ve ahlaklı insanlar oluşur. Hacılar burada fazla eşyalarının bir kısmını dönüşte almak üzere emanete bırakırlar. Kafile el-'Ulâ'da iki ila dört gün olmak üzere konaklar, ihtiyaçlarını temin ederler, elbiselerini yıkarlar. Şâm yöresinin Hıristiyan tüccarları el-'Ulâ'ya kadar gelseler dahi daha ileri geçemezler. Burada hacılara azık, yolluk vesaire satarlardi. ${ }^{158}$

Kafile el-'Ulâ'dan Hüdeyye'ye ${ }^{159}$ gitmek üzere yola koyulurdu. Hüdeyye ve el-'Ulâ arası yaklaşık 5 merhaledir. ${ }^{160}$ el-'Ulâ'dan hareket ettikleri günün ertesi Attâs Vadisi'ne inilir. Burası çok sicaktır. Öldürücü semûm yeli burada eser. Bir seferinde kafile şiddetli bir semûm yeline tutulmuş da pek az kimse kurtulmuş. O seneye "Emîr Câlıkî senesi" denmiş. Attâs Vadisi'nden yola devam edilerek Hüdeyde'ye varılır. Hüdeyde, oradaki vadide yeraltından çıkan su sızıntısıdır. Eşeleyip çıkarırlar ama suyun lezzeti yoktur. Hüdeyye'nin suları içime elverişli olmayacak kadar tuzludur. Çukur olduğu için sel suları burada birikir. Bu sudan içenin midesi guruldamaya başlar ve ardından da ishale yakalanır. Ancak ilaçla tedavi edilebilir. ${ }^{161}$ Hüdeyye'nin suları ancak yağmurlu mevsimde sel suları ile beslendiği zaman içilebilir hale gelirdi. Hatta bazı yıllar burada büyük nehirler gibi sel suları akardı. Ansızın bastıran yağmurların oluşturduğu ve kumla karışıp balçık halini alan bu sellerde boğulanlar dahi olurdu. ${ }^{162}$ Kafile Hüdeyde'den sonra 5 merhale daha giderek 'Uyûnu Hemze' ye varırdı. Bu ikisi arasinda bulunan 'Atab, el-'Akabetü's-Sevdâ', el-'Uzâm Vadisi ve en-Nahleteyn mevkileri oldukça meşakkatliydi. Pek çok hacı senelerce ansızın meydana gelen seller yahut aşırı sıcaklar sebebiyle ölmüsstü. Yazın sıcağında dahi aniden bastıran yağmurun sebep olduğu seller, dağların eteklerinden boşalır, dar boğazlardan geçerek ivme kazanır, hacıların kaçmasına olanak vermezdi. Ayrıca kumları ve kayaları adeta köze çeviren, bütün su kaynaklarını kurutan semûm yeli de pek çok hacı ve devenin ölümünden mesuldü. ${ }^{163}$ Kafile 'Uyunu Hemze'den sonra ise Medine gelirdi.

Ancak Memlûklerin son zamanlarında yahut Osmanlının Mısır ve Şâm'daki ilk dönemlerinde bu hac rotasının menzillerinin bir kısmının değiştiği anlaşılmaktadır. Cezîrî bu rotayı ve menzilleri şöyle tarif eder: "Kubbetü Yelboğa kafilenin ilk menzilidir ve kafile burada yedi gün kalırdl. Ardından Kubbetü'l-Hacc'a gider ve burada iki gün kalırdl. Burası nehirlerin aktığl, içimi hoş suların olduğu bir yerdi. Kafile Kubbetü'l-Hacc'dan sonra Cisrü'l-Kusve'ye ulaşırdl. Burada el-A'rec Nehri bulunurdu. Kusve'den sonra bir akarsuyun yanina kurulmuş Zü'n-Nûn Hanı'na ulaşılırdı. Bu handan sonra Kuteybe'ye ulassılırdı. Kuteybe'de eski bir han ve bir su pinarinin bulunduğu ve bu sebeple kafilelerin rağbet ettiği bir yerdi. Bir sonraki durak el-Müzeyrîb idi. Burada inşası yeni bitmiş bir kale bulunurdu. Kafile el-Müzeyrîb'de yedi gün kaldıktan sonra yoluna devam eder, et-Taktîr'e ve oradan da Ezra'ât'a giderdi. Ezra'ât,

\footnotetext{
155 İbn Battuta, Seyahatnâme, s. 119; Eyüp Sabri Paşa, Mir'âtü'l-Cezireti'l- 'Arab, s. 176-177.

${ }^{156}$ Eyüp Sabri Paşa, Mir'âtü'l-Cezireti'l- 'Arab, s. 178.

${ }^{157}$ Cezîrî, ed-Dürer, C. 2, s. 63.

${ }^{158}$ İbn Battuta, Seyahatnâme, s. 119; Cezîrî, ed-Dürer, C. 2 , s. 63.

${ }^{159}$ Eyüp Sabri Paşa bu beldenin adını Şâbu'n-Na'âm olarak verir, Mir'âtü'l-Cezireti 'l- 'Arab, s. 171.

160 'Ömerî, Mesâlikü'l-Ebsâr, C. 2, s. 344.

161 İbn Battuta, Seyahatnâme, s. 119.

162 'Ömerî, Mesâlikü'l-Ebsâr, C. 2, s. 344; Cezîrî, ed-Dürer, C. 2, s. 63-64.

163 'Ömerî, Mesâlikü'l-Ebsâr, C. 2, s. 345; Cezîrî, ed-Dürer, C. 2, s. 64.
} 
Bilâdu Hevrân' in son mamur ve yerleşik köyü olup burada su kuyuları bulunurdu. Ezra'ât'dan sonra suyun bulunmadĭ̆ bir tepe üzerine kurulmuş eski bir han olan Hânu'l-Müferrik'e ulaşılırdı. Ardından bir pinarın bulunduğu ez-Zerkâ' menziline varılırdı. Ez-Zerkâ'da tepe üzerinde Kasru Şebîb bulunurdu. Buradan hiç suyun bulunmadiğı el-Belkâ'nın ilk yerleşim yeri olan Re'su Balâta'ya varllırdı. Re'su Balâta'dan hareket eden kafile Hânu Kıyadi Sahren 'i geçtikten sonra ikindi vakti susuz bir yer olan Hânu'l-Katrânî'ye inerdi. Eskiden kafileler Hânu'l-Katrânî'den el-Lecûn denilen eski bir köye inerler ve burada üç gün kalırlar ve akabinde Kerek'e inerlermiş. Ama bu uygulama yaklaşık sekiz sene önce terkedilmiş ve bunun yerine artık el-Hisấ'ya iniliyor. Bir akarsuyun bulunduğu el-Hisâ'da yemyeşil bir ovadır. Tacirler buraya arpa, tavuk ve başka şeyler getirip satarlar. Kafile el-Hisấ'da kalmadan Hanu 'Uneyze'ye doğru hareket eder. Bu konağın olduğu mahalde yaz klş soğuk eksik olmazdl. Buranın Arapları eğer kafile reislerinden razı iseler kafile için Şevbek'ten erzak getirirler ve hacılara satarlardl. Kafile yoluna devam eder ve akan kaynaklar bulunduğu, ara sira tüccarlarından uğradĭ̆ı Ma'ân'a giderdi. Ma'ân'dan eş-Şeyyidiyye şeklinde isimlendirilen 'Akabetü's-Savân'a, et-Tubeyliyye'ye ve bilahare çukurluk bir yer olan Tezvîdetü Sarar geçilerek ve Zâtü Hacc'a varılırd. Burada et-Tâbût adı verilen mübarek bir yer bulunurdu. Rivayete göre Hz. Peygamber burada elleri ile topră̆ı kazmış ve su çıkmıştı. Çıkan bu suyun hemen yanında eskiden inşa edilmiş bir sarnıç bulunurdu. Yaklaşık beş sene boyunca hacılar buradan su içmişlerdi. Buradan dümdüz bir yer olan ne bir tepenin ne de su kaynağının olduğu Buseyta Ovası'na gidilirdi. Buseyta'dan da Tebük göletine inilirdi. Bu gölet oldukça büyük olup etrafi mamur ve hurmallk olup hemen yakınında Tebükü'l-Kadîme adı verilen bir su kaynağl vardl. Hz. Peygamber buraya gazvede bulunmuştu. Kafile buradan sonra Karandeliyye adlı bir mağara önünde konaklardl. Bu menzil Araplar arasında Haşîmu Birek adlyla maruftu. Karandeliyye'den sonra sirasıyla 'Akabetü'l-Uheyder ile 'Akabe geçilir ve Uheyder Kalesi'ne varılırdı. Kalenin ortasında kuyu bulunurdu. Dışında ise üç tane sarnıç bulunurdu ve kuyudan bu sarnıçlara deve sırtında su taşınırdı. Bazı tüccarlar buraya ot, balık ve koyun getirilerdi. Uheyder Kalesi'nden sonra es-Sânî ve Ebû Hubeyb Vadileri geçilir ve Birketü'l-Mu'azzam'a inilirdi. Burası büyük bir sarnıç olup sel suları doldururdu. Birke'den el-'Akayri' ve Şakku'l-'Acûz denilen yere varllırdl. Bu mevkide bazl vakitler yağmurlardan kaynakl su bulunurdu Buradan sonra Hz. Peygamber'in oturduğu mübarek yer geçilir el-Hicr Kuyuları'na ve Medâinu Sâlih'e gidilirdi. İbn Havkal "Takvîmu'l-Buldân" adlı eserinde şöyle der: "el-Hicr dağlar arasındadır. el-Kurâ Vadisi'nden bir gün uzaklıktadır. Hacılar ise bu mesafeyi en fazla beş günde katederler. el-Hicr kayaları oyan Semûd kavminin kayaları oyduğu vadidedir. Ben Allah'ın Kuran-ı Kerîm'de bahsettiği ${ }^{164}$ bu oyulmuş kayaların olduğu dağ gördüm. Bu dă̆a el-Esâlib adı verilir. Bu dă̆ Şâm hacılarının indiği dă̆ olup el-'Ulâ'dan Şâm tarafina doğru yarım merhale uzakliktadır. Rivayetlere göre Hz. Peygamber buranın suyunu içilmesini yasaklamıştır." Hicr Kuyuları'ndan sonra büyük bir pınar bulunduğu el'Ulâ'ya varılırdı. Pınarın bulunduğu yerde tüccarların ticaret yaptığ hurmallk bir köy vardır. Kafile burada 2 gün konaklar ve ardından Matareyn'e gidilirdi. Matareyn, Hafâiru'z-Zemûd yakınlarında düz ve geçimi kolay bir arazidir. Matareyn'den Araplar arasinda Dâru'l-Hamrâ' adıyla bilinen Ş'abu'n-Na'âm'a varılır ve yola devamla Hüdeyye ve Mâlih'e geçilirdi. Bu ikisinin sulart fazla tuzlu olduğu için içime uygun değildir. Mâlih'ten ne ot ne de içilecek suyun bulunduğu Fahleyetn'e varllır ve ardından yağmur suları hariç suyun bulunmadiğ Nakbu 'Alî'ye gelinirdi. Kafile yoluna devam edip el-Kurâ ve el-'Akîk Vadileri geçildikten sonra 2 gün kalacă̆ı Hamza Kuyuları'na varılırdı. Bu mevkide artık mahmil süslenirdi. Zira burası Medine'nin konağıdır. Kafile yoluna devam eder ve 'Alî Kuyularına giderdi. Bu kuyular

164 Şuarâ Suresi/149, “Ve Tenhıtûne min'el-Cibâli Buyûten Fârihîne: Bir de dağlardan ustalıkla evler yontuyorsunuz", https://kuran.diyanet.gov.tr/tefsir/Suarâ-suresi/3078/146-150-ayet-tefsiri 
hacıların ihrama girdiği Zu'l-Huleyfe'dedir. Şühedanın kabirleri geçildikten sonra elCüdeyyide, Huleys, el-Munhenâ Vadisi, Derbu Ebî 'Urve, Zâhir Vadisi geçilir. Burada Sebîlu'l-Cevhî vardır. Akabinde de Mekke'ye varllır. ${ }^{165}$

\section{Sonuç}

Hac, 630 yılında Müslümanlar üzerine farz olunduğundan itibaren ifası için en çok gayret gösterilen ibadet olmuştur. Şartlarına gücü yeten milyarlarca Müslüman yüzyıllardan beri üzerlerine farz olan bu ibadeti yerine getirmek için maddî, manevî ve fizikî şartlarını zorlayarak dünyanın dört bir yanından Kâbe'ye akın etmişlerdir. Sultan ez-Zâhir Baybars tarafından 1261 y1lında, 1258 yılında Moğollar tarafından son verilen Abbâsî Hilafeti'nin Kâhire'de ihyası ile Müslümanların hac işleri ve Hicaz bölgesine dair her türlü mesele Memlûkler Devleti sultanlarının uhdesi altına girmiştir. ez-Zâhir Baybars 1266 yılından itibaren de Kâhire'den Mekke'ye törenler eşliğinde mahmil gönderme uygulamasını başlatarak hac ibadeti sebebiyle Mekke'deki kutsal mekanlarda toplanmış olan Müslümanlara Memlûkler Devleti'nin gücünü ve kudretini sergilediği siyasî bir simge oluşturmuştur. Mahmil gönderme uygulaması, yıkılana kadar Memlûklerin diğer devletler nezdinde en önemli imtiyazlarından birisi olmuş ve sultanlar tarafından da ihtimam gösterilmiştir. Zaman içinde Mısır'ın merkezi Kâhire'den gönderilen mahmile, Bilâdu'ş-Şâm'ın merkezi Dımaşk'tan gönderilen bir ikinci mahmil daha eşlik etmeye başlamıştır. Tıpkı Msır mahmili gibi bu mahmile de büyük önem atfedilmiş, hususî törenlerle Şâm hac yolunu kullanan Müslümanlarla kutsal beldeye gönderilmiştir.

Şâm hac yolunu kullanan Müslümanlar, kendilerini devlet namına sağ ve salimen hacca götürmek ve getirmek, imkânlar nispetinde yolculuk boyunca ve Hicaz'da hacilara her türlü yardımı ve kılavuzluğu sağlamak maksadıyla bizzat sultan tarafından tayin edilmiş ve yolculuk müddetince hacılar üzerinde her türlü yetki ve salahiyete sahip hac emirinin riyasetinde ibadetlerini ifa etmişlerdir. Hac emîrliği vazifesine layık olmak için pek çok üstün vasıflara sahip olması gereken emîrler arasından seçilen hac emîrleri, bazı yıllar görevlerini olması gerektiği gibi ifa etmekten imtina etmişler ve ihmalleri sebebiyle en önemli vazifeleri olan yol güvenliğini sağlamakta başarısız olmuşlardır. Bunun neticesi olarak da Arap kabilelerinin saldırıları neticesinde pek çok Müslüman canlarından ve mallarından olmuşlardır. Müslümanların bu meşakkatli ve uzun yolculukta başlarına gelen diğer bir olumsuz hadise ise susuzluk, açlık, kuraklık ve sel baskınları gibi tabi afetlerdi. Hacılar, insanın yaradılışından kaynaklı suya olan zafiyetinden dolayı, özellikle yaz aylarında su olanakları kısıtlı Hicaz bölgesinde büyük zorluklara düçar olmuşlar, pek çoğu hayatlarını kaybetmiştir.

\section{Kaynakça}

Ahmed er-Reşîd, Hüsnü's-Safâ ve'l-İbtihâc bi-Zikri Men Vuliye Imâreti'l-Hâcc, Thk. Leylâ 'Abdüllâtif Ahmed, Mektebetü'l-Hânci bi-Misr, Kâhire 1980.

Al-Ahmad, Muhammed Ali, “et-Te'sîratü' l-'Usmâniyye 'alâ Tarîkey el-Hacci'ş-Şâmî ve'lMırrî”, Akademik Platform İslami Araştırmalar Dergisi, S. 3/1, 2019, s. 64-82.

'Âşûr, Sa'îd Abdu'l-Fettâh, el-Asru'l-Memâlîkî fî Misr ve'ş-Şâm, Dâru'n-Nehdeti'l-'Arabiyye, Kâhire 1976.

ATALAR, Münir, "Emîr-i Hac". Türkiye Diyanet Vakfi İslâm Ansiklopedisi, S. 11, TDV Yayınları, İstanbul 1995, s. 131-133.

ATEŞ, İbrahim. "Osmanlılar Zamanında Mekke ve Medine'ye Gönderilen Para ve Hediyeler". Vakıflar Dergisi, S. 13, 1981, s. 113-170.

${ }^{165}$ Cezîrî, ed-Dürer, C. 2, s. 65-67. 
AYAZ, Fatih Yahya, Bahrî Memlukler Döneminde Harameyn Hizmetleri, (Marmara Üniversitesi Sosyal Bilimler Enstitüsü, Yüksek Lisans Tezi), İstanbul 1998.

'Aynî, Bedreddîn Mahmûd b. Ahmed, 'íkdu'l-Cumân fì Tarîhi Ehli'z-Zamân, Thk. Muhammed Muhammed Emîn, C. 4, el-Hey'eti'l-Misriyyeti'l-'Amme li'l-Kitâb, Kâhire 1992.

BALCI, İsrafil, "Şam Bölgesi Fetihleri”, İslâm Tarihi ve Medeniyeti. S. 2, Siyer Yayınları, İstanbul 2018, s. 165-195.

BELAZURI, Ahmed b. Yahya. Fütûhuhu'l-Buldân, Terc. Mustafa Fayda, Siyer Yayınları, İstanbul 2013.

Berzâlî, 'Alemuddîn Ebî Muhammed el-Kasım b. Muhammed b. Yusuf, el-Muktefí alâ Kitabi'r-Ravzateyn el-Marûf bi-Târihi'l-Berzâlî, C. 4, Thk. Ömer Abdüsselam Tedmûrî, Mektebetü'l-Asriyye, Beyrut 2006.

BUHL, Fr, "Mahmel”, İslâm Ansiklopedisi, C. 7, Milli Eğitim Basımevi, İstanbul 1977, s. 151153.

BUSREVÎ, 'Alâeddîn Alî b. Yûsuf b. Ahmed ed-Dımaşkî, Tarîhu'l-Busrevî, Thk. Ekrem Hasan el-'Ulebî, Dâu'l-Me'mûn li’t-Turâs, Beyrut 1971.

CEZÎRÎ, 'Abdulkâdir b. Muhammed, b. 'Abdulkâdir b. Muhammed el-Ensârî, ed-Dürerü'lFerâidi'l-Munazzamati fì Ahbâri'l-Hacc, C. 2, Thk. Muhammed Hasan Muhammed Hasan İsmâ'îl, Dâru'l-Kutubi'l-'İlmiyye, Lübnan 2002.

ÇETIN, Altan, Memlûk Devletinde Askerî Teşkilât, Eren Yayıncılık, İstanbul 2007.

ÇETIN, Cemal, "Osmanlılarda Mesafe Ölçümü ve Tarihî Süreci”, Prof. Dr. Nejat Göyünç Armağanı, Ed. Hasan Bahar vd, Türkiyat Araştırmaları Enstitüsü, Konya 2013, s. 443466.

DI VARTHEMA, Ludovico, The travels of Ludovico di Varthema in Egypty, Syria, Arabia Deserta and Arabia Felix, in Persia, India, and Ethiopia, A. D. 1503 to 1508, Terc. John Winter Jones, Neşr. G. P. Badger, The Hakluyt Sociesty, London 1863.

EREN, Cüneyt-Yıldız, Muharrem, “Kur'an-1 Kerim ve Kitâb-1 Mukaddes'te Şuayb Aleyhisselam". Dinbilimleri Akademik Araştırma Dergisi, S. 2, 2002, s. 107-132

ERKAL, Mehmet. "Hac Emîrliği (Yönetimi) ve Bununla İlgili Bazı Fıkhi Meseleler". Sakarya Üniversitesi Illahiyat Fakültesi Dergisi, S. 4, 2001, s. 145-161.

EROL, Burak Gani, "Memlûkler Zamanında Mısır Mahmili”, Türkiyat Mecmuası, S. 29/1, 2019, s. 45-80.

EROL, Burak Gani, "Memlûkler Zamanında Mısır Hac Güzergâhı - Kâhire'den Mekke’ye Uzanan Kutsal Yolculuk", Recep Tayyip Erdoğan Üniversitesi Ilahiyat Fakültesi Dergisi, S. 16, (Aralık 2019), s. 264-314.

EROL, Burak Gani, "Memlûk Sultanlarının Hacları", Tarih Okulu Dergisi, S. 12/XL, Haziran 2019, s. 312-355.

Eyüp Sabrî Paşa, Mir'âtü'l-Cezîreti'l- 'Arab, Thk. Ahmed Fu'ad Mütevellî-es-Safsâfî Ahmed el-Mursî, Dâru'l-Âfaki'l-'Arabiyye, Kahire 1999.

Eyüp Sabri Paşa, Mir'âtü'l-Haremeyn, C. 2, Haz.: Ömer Fâruk Can-F. Zehra Can, Türkiye Yazma Eserler Kurumu Başkanlığı Yayınları, İstanbul 2008. 
FAHD, Bedri Muhammed, "Hacc Emîrleri Tarihi”, Diyanet Illmi Dergi, Çev. Münir Atalar, S. 33/1 1997, s. 37-72.

FÂSÎ, Takıyyüddîn, Şifâu'l-Ğarâm bi-Ahbâri'l-Beledi'l-Harâm, C. 2, Thk. Alî Ömer, Mektebetü's-Sekâfeti'd-Dîniyye, Kâhire 2008.

HALAÇOĞLU, Yusuf, "Fersah", Türkiye Diyanet Vakfi İslâm Ansiklopedisi, C. 12, TDV Yayınları, İstanbul 1995, s. 412.

HAMIDULLAH, Muhammed, "Hz. Peygamber'in İslâm Öncesi Seyahatleri”, Terc. Abdullah Aydınl1, Atatürk Üniversitesi İslamî İlimler Fakültesi Dergisi, S. 4, 1980, s. 327-345.

IŞIK, Emin, "Kureyş Sûresi Üzerine Bir Tefsir Denemesi", Marmara Üniversitesi Ilahiyat Fakültesi Dergisi, S. 3, 1995, s. 9-14.

İbn Battuta, Ebû 'Abdullah Muhammed et-Tancî, İbn Battûta Seyahatnâmesi, Çev. A. Sait Aykut, Yap1 Kredi Yayınları, İstanbul 2013.

İbn Fehd, en-Necm Ömer, İthâfü'l-Verâ bi-Ahbâri Ümmi'l-Kurâ, C. 5, Thk. Fehîm Muhammed Şeltût, Mektebetü'l-Hâncî, Kâhire 1983.

İbn Hacer El-'Askalanî, Ebû'l-Fazl Şihâbüddîn Ahmed b. Alî b. Muhammed, İnba'u'l-Ğumr bi Ebnai'l-'Umr, C. 4, Thk. Hasan Habeşî, el-Meclisu'l-'A'layi li'ş-Şu'ûni'l-İslamiyye, Kâhire 1969.

İbn İyâs, Muhammed b. Ahmed, Bedâ'iu'z-Zuhûr fî̀ Vakâi'i'd-Duhûr, C. 5, Thk. Muhammed Mustafâ, el-Hey'etü'l-Mısriyyeti'l-'Ammeti'l-Kutub, Kâhire 1984.

İbn Kâdı Şühbe, Takıyyüddîn, Tarihu İbn Kâdı Şühbe, C. 4, Thk. 'Adnân Dervîş, el-Ma'hadu'l'İlmi el-Fransî Li'd-Dirâseti'1-'Arabiyye, Dımaşk 1977-1994.

İbn Kesîr, Ebû'l-Fidâ', el-Bidâye ve'n-Nihâye, C. 21, Thk. Abdullah b. Abdu'l-Muhsin etTürkî, Hecr, Cîze 1998.

İbn Sasrâ, Muhammed b. Muhammed, ed-Dürretü'l-Mudî'e fi'd-Devleti'z-Zâhiriyye, Thk. William M. Brinner, University of California Press, Berkeley 1963.

İbn Tolun, Şemseddîn, I'lâmü'l-Verâ bi-men Vulliye Nâiben mine'l-Etrâk bi-Dımaşki'l-Kübrâ, C. 2, Thk, 'Abdülazîm Hâmid Hattâb, Matba'tu Cami’ati ‘Ayni Şems, Kâhire 1973.

İbn Tolun, Şemseddîn, Müfâkehetü'l-Hillân fí Havâdisi'z-Zamân, Thk. Halil el-Mansûr, Dâru'l-Kutubi'l-'İlmiyye, Beyrut 1998.

İbnü'l-Cezerî, Şemseddîn, Havâdisü'z-Zamân ve Enbâuhu ve Vefeyâtü'l-Ekâbir ve'l-A'yân min Ebnâihi, el-Ma'rûf bi-Tarîhi İbni'l-Cezerî, C. 2, Neşr. Ömer A. Tedmürî, Mektebetü'lAsriyye, Beyrut 1998.

JOMIER, J. "Mahmel", The Encylopaedia of Islam (New Edition), C. 6, E. J. Brill, Leiden 1991, s. 44-46.

KALKAŞENDÎ, Ebû'l-'Âbbâs Ahmed b. 'Ali, Subhu'l-'Aşấ fî Sinâ'ati'l-Inşâa, C. 14, Dâru'lKutubi'l-Misriyye, Kâhire 1922.

KELEŞ, Bahattin, "Memlûkler Döneminde İdarî Yapı", Türkler Ansiklopedisi, C. 5, Yeni Türkiye Yayınları, Ankara 2002, s. 589-609.

KÜÇÜKAŞÇI, Mustafa Sabri, Abbasiler'den Osmanlılar'a Mekke-Medine Tarihi, Yeditepe Yayınevi, İstanbul 2007. 
MAKRÎZÎ, Takiyyü'd-Dîn Ahmed b. 'Ali, el-Mevâ'izü'l-i'tibâr bi-Zikri'l-Hitat ve'l-Asâr, C. 3, Thk. Muhammed Zeynuhum-Medîha eş-Șerkâvî, Mektebetü Medbûlâ, Kâhire 1998.

MAKRÎZÎ, Takiyyü'd-Dîn Ahmed b. 'Ali, es-Sülûk li-Ma'rifeti'd-Düveli'l-Mülûk, C. 8, Thk. Muhammed 'Abdu'l-Kâdir 'Atâ, Dârü'l-Kutubi'l-'İlmiyye, Kâhire 1997.

MAKRÎZÎ, Takiyyü'd-Dîn Ahmed b. 'Ali, ez-Zehebu'l-Mesbûk fî Zikri Men Hacce mine'lHulefâ' ve'l-Mülûk, Thk. Cemâlü'd-Dîn eş-Şeyyâl, Mektebetü't-Sekâfeti'd-Dîniyye, Bûr Sa'îd 2000.

MUTÇALI, Serdar, Arapça-Türkçe Sözlük, Dağarcık Yayınları, İstanbul 1995.

ÖĞÜT, Salim, "Hac: Hacla İlgili F1khî Hükümler", Türkiye Diyanet Vakfı İslâm Ansiklopedisi, C. 14, TDV Yayınları, İstanbul 1996, s. 389-397.

'Ömerî, Şehâbü'd-Dîn Ahmed b. Yahyâ, Mesâlikü'l-Ebsâr fì Memâliki'l-Emsâr, C. 27, Thk. Kâmil Selmân el-Cubûrî-Mehdî en-Necm, Dâru'l-Kutubi'l-'İlmiyye, Lübnan 1971.

ÖZEL, Ahmet, "Hac (Seyahatnâmeler)", Türkiye Diyanet Vakfi İslâm Ansiklopedisi, C. 14, TDV Yayınları, İstanbul 1996, s. 413-414.

SARIÇAM, İbrahim, "Hâşim b. Abdümenâf”, Türkiye Diyanet Vakfi İslâm Ansiklopedisi, C. 16, TDV Yayınları, İstanbul 1997, s. 405-406.

ŞEŞEN, Ramazan, Sultan Baybars ve Devri: 1260-1277, İsar Vakfi Yay., İstanbul 2009.

UZUNÇARŞILI, İsmail Hakkı, Osmanlı Devleti Teşkilatına Medhal, Türk Tarih Kurumu Yayınları, Ankara 1984.

Yakut el-Hamavî, Ebû 'Abdillâh Şihâbiddîn Yakut b. 'Abdillâh, Mu'cemu'l-Buldân, C. 5, Dâru Sâdır, Beyrut 1977.

YÛNÎNÎ, Kutbüddîn, Zeylu Mir'âti'z-Zamân, (el-Mektebetü'ş-Şâmile).

YÛNÎNÎ, Kutbüddîn, Zeylu Mir'ati'z-Zamân, C. 22, Thk. 'Abbâs Hânî el-Cerrâh, Daru'lKutubil 'İlmiyye, Beyrut 2013.

ZEHEBÎ, Şemseddîn Muhammed b. Ahmed b. Osman, Târîhu'l-İslâm ve Vefeyâtü'l-Meşâhîr ve'l-A 'lâm, C. 53, Neşr. Ömer A. Tedmûrî, Dâru'l-Kütübi'l-Arabî, Beyrut 1999. 
EK 1: Tebük Yolu ve Menzilleri
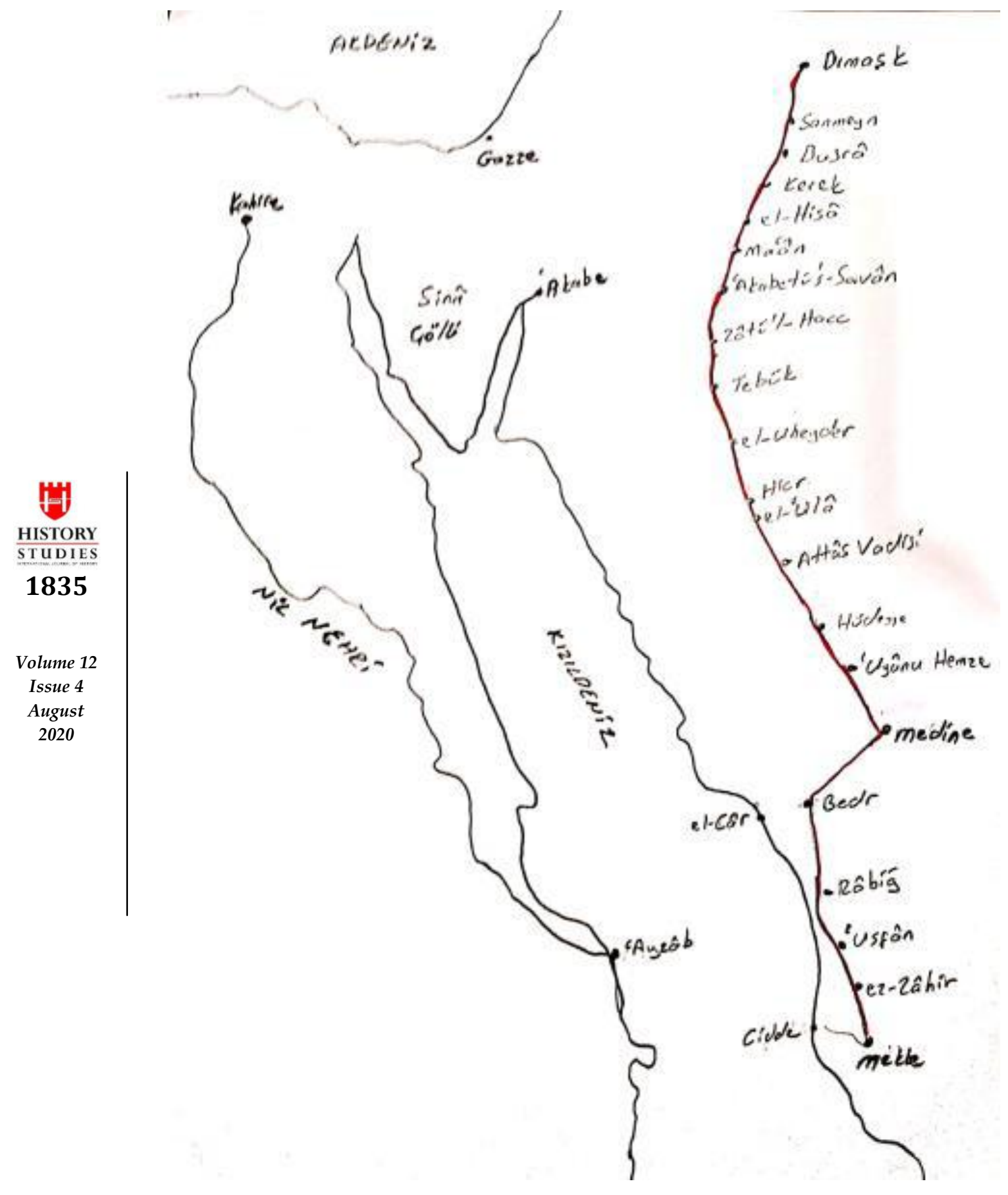